MYKOL ROMERIO
UNIVERITEIAS

\title{
AGRARINIS LOBIZMAS EUROPOS SAJUNGOJE IR LIETUVOJE
}

\author{
Vygandas Paulikas \\ Mykolo Romerio universiteto Politikos ir vadybos fakulteto \\ Politikos mokslų institutas \\ Valakupių g. 5, LT-10101 Vilnius, Lietuva \\ Telefonas (+370 5) 2714589 \\ Elektroninis paštas vpaul@mruni.eu \\ Linas Jonas Gustas \\ Mykolo Romerio universiteto Politikos ir vadybos fakulteto \\ Politikos mokslu institutas \\ Valakupiu g. 5, LT-10101 Vilnius, Lietuva \\ Telefonas (+370 6) 7690277 \\ Elektroninis paštas linasg@dtiltas.lt
}

Pateikta 2013 m. kovo 1 d., parengta spausdinti 2013 m. liepos 15 d.

doi:10.13165/SMS-13-5-3-08

Anotacija. Straipsnyje nagrinëjama Lietuvos žemdirbiu organizacijų lobistinè veikla Lietuvos ir Europos Sajungos (ES) institucijose. Nustatyta, kad Lietuvos žemdirbiu lobistine veikla turi pliuralizmo ir korporatyvizmo bruožu. Taip pat aprašyta lobistine veikla Europos Komisijoje (EK), Europos Parlamente (EP) ir Europos Taryboje (ET). Atlikta Lietuvos žemdirbiu organizaciju vadovu bei valstybès tarnautoju apklausa apie žemdirbiu interesus, žemdirbiu lobistines veiklos metodų efektyvuma, prieigos taškus ir žemdirbiu konkurentus vykdant lobistine veikla. Taip pat atlikta žemdirbiu organizaciju vadovu, valstybès tarnautoju ir politiku atsakymu lyginamoji analize.

Reikšminiai žodžiai: pliuralizmas, korporatyvizmas, klientelizmas, agrolobizmas, Lietuvos žemès ükio interesu grupès, Europos Komisija, Europos Parlamentas, Europos Taryba, Lietuva, interesai. 


\section{Ivadas}

Lietuvos žemdirbiams sunku konkuruoti ES rinkoje su Jungtinės Karalystės, Vokietijos, Danijos ir kitų šalių ūkiais. Lietuvoje ị rinką orientuotų stambių ūkių yra mažai ir jie gauna daug mažesnes tiesiogines išmokas nei kitų ES šalių žemdirbiai, be to, Lietuvoje sąlygos žemės ūkiui ne tokios palankios kaip kitose ES šalyse, o žemės ūkio produkcijos supirkimo kainos mažesnès už ES vidurkị ${ }^{1}$. Todèl, siekiant išlikti rinkoje, Lietuvos žemdirbiams reikia imtis lobistinès veiklos Lietuvos ir ES institucijose ir siekti tiesioginių išmokų suvienodinimo, palankesnio žemės ūkio produkcijos gamybos reglamentavimo. Tačiau Lietuvos žemdirbiai nepakankamai aktyvūs ES institucijose, jiems trūksta lobistinès veiklos igūdžių, be to, žemdirbiai kartais taiko netinkamus lobizmo metodus ir ne visada teisingai vertina Lietuvos ir ES institucijų įtaką bendros žemès ūkio politikos (BŽŪP) formavimui. Dèl šiu priežasčiu Lietuvos žemdirbiams nepavyksta apginti savo interesų Lietuvos ir ES institucijose, ir daugeliui Lietuvos žemdirbių kyla bankroto grèsmè. Lietuvos žemdirbių organizacijų lobizmo metodai, ir ypač jų dažnai praktikuojamos apeliacijos ị Lietuvos institucijas, neužtikrina sèkmingo žemdirbių interesų gynimo.

Šio straipsnio tyrimo objektas - Lietuvos agrarinių lobistų veikla ES institucijose. Pagrindine tyrimo problema - Lietuvos agrarinių lobistų veiklos ES institucijose tikslai, priemonès, darbo metodai, lobistinis personalas, šios veiklos privalumai, pasiekimai, trūkumai ir jų priežastys. Darbo tikslas - ištirti Lietuvos agrarinių lobistų veiklą ES institucijose (ivertinti jos veiksmingumą ir tolesnio tobulinimo kelius), atskleisti jos dèsningumus, pasiūlyti praktines rekomendacijas.

Straipsnyje siekiama ištirti ES lobistų registrus, Lietuvos agrarinio eurolobizmo organizacinę struktūrą, įvertinti lobistų personalinès sudèties kokybinius aspektus, lobistu veiklos planavimą, vyksmą ir igyvendinimą Lietuvoje ir Briuselyje bei išsiaiškinti Lietuvos agrarinio eurolobizmo sistemą, apibendrinti pasiektus rezultatus ir tolesnes perspektyvas po 2014 m., patirti, nustatyti (išryškinti, suformuluoti) veiklos dėsningumus. Siekiama konkrečių atvejų analize atskleisti priežastis, kurios nulemia eurolobizmo veiksmingumą.

Straipsnyje keliama hipotezè, kad sėkmingesniam Lietuvos žemdirbių interesų atstovavimui Lietuvos ir ES institucijose trūksta įmantresnių ir modernesnių lobizmo technologijų taikymo. Hipotezei pagristi pasitelkiami priklausomi ir nepriklausomi kintamieji. Priklausomi kintamieji - agrarinès interesų grupės (IG), de facto institucinè aplinka; Lietuvos Europos agrarinès politikos koordinavimo sistema; ES institucijų bendradarbiavimo su agrarinėmis interesų grupėmis preferencijos ir europinè atstovavimo žemès ūkio interesams sistema. Nepriklausomi kintamieji - istorinis palikimas.

Straipsnyje lobizmo reiškinys aiškinamas, remiantis Lietuvos Respublikos (LR), ES ir Jungtinių Amerikos Valstijų (JAV) lobizmo teisès aktais (LR lobistinès veiklos

1 Žemės ūkio rūmų prezidiumo rezoliucija „Dèl bendrosios žemės ūkio politikos po 2013 m.“ “ interaktyvus]. [žiūrèta 2011-12-13]. <http://www.zur.lt/index.php?-1190738131>. 
ịstatymas ${ }^{2}$, EK 2007 m. žalioji knyga ${ }^{3}$ ir JAV 1995 m. lobizmo viešumo (atskleidimo) aktas $\left.^{4}\right)$. Remiantis interesų grupių ir valdžios institucijų sąveikos pliuralizmo, korporatyvizmo ir klientelizmo metodologiniais modeliais, aptariamas lobizmo reiškinio ir šiu metodologinių modelių ryšys su šalyje vyraujančia politine sistema.

Susipažinus su Lietuvos ir užsienio mokslininkų darbais, nustatyta, kad Lietuvos ir užsienio mokslininkai mažai tyrè Lietuvos žemdirbių lobistinès veiklos metodus, privalumus ir trūkumus, ir žemdirbių konkurentus vykdant lobistinę veiklą ir netyrẻ ịtakingų valstybės tarnautojų ir politikų nuomonès apie žemdirbių lobistinę veiklą, taip pat nepateikè pakankamai rekomendacijų, kaip tobulinti žemdirbių lobistinę veiklą.

\section{Literatūros apžvalga}

Rašant ši straipsni buvo remtasi Lietuvos ir užsienio moksliniais straipsniais ir straipsnių autorių surinktais duomenimis bei atliktais tyrimais, ES institucijų parengtais dokumentais. Pagrindinis darbe naudojamas literatūros šaltinis yra užsienio ir Lietuvos autorių literatūra, kaip, pavyzdžiui, teoretikų: S. Hikso, R. Hrebenaro, A. Lukošaičio, J. Vilčinsko, D. Vijeikio, D. Trakelio, Ž. Šukytès, Eurostato pateikti duomenys. Taip pat pateikiami šio straipsnio autorių atliktos Lietuvos žemdirbių organizacijų vadovų bei su žemės ūkiu susijusių valstybės tarnautojų ir politikų apklausos rezultatai.

Laima Andrikienẻ su bendraautoriais, apžvelgdami lobistinę veiklą Lietuvoje, konstatavo, kad Lietuvos visuomenè lobizmo dažnai neskiria nuo korupcijos ir kad Lietuvoje trūksta profesionalių lobistų, o tuometinis LR veikiantis Lobistinès veiklos ịstatymas pasižymėjo gausiais sisteminiais trūkumais (nuo $2003 \mathrm{~m}$. veikia kitas ịstatymas, tačiau tik dalis trūkumų buvo ištaisyti). Šiame straipsnių rinkinyje pateiktas išsamus lobistinès veiklos aprašymas ES, JAV, Japonijoje ir rekomendacijos, kaip Lietuvos IG turètų vykdyti lobistinę veiklą: stebèti valdžios veiksmus, užmegzti ir palaikyti ryšius su valdžia, ieškoti kitų IG paramos ${ }^{5} .2013$ m. paskelbtame Rimgaudo Geleževičiaus straipsnyje teigiama, kad dèl Lietuvos visuomenès tradicijų ir visuomenès požiūrio ị lobizmą teisinis lobizmo reguliavimas Lietuvoje yra neefektyvus, todèl Lietuva turètu atsisakyti lobizmą reglamentuojančių teisès aktų .

2006 m. ir 2008 m. JAV mokslininkas Ronaldas Hrebenaras su bendraautoriais tyrè Lietuvos IG veiklą ir prièjo prie išvados, kad jos netaiko Vakaruose ịprastų lobiz-

2 Lietuvos Respublikos lobistinès veiklos ịstatymas [interaktyvus]. [žiūrèta 201-05-18]. <http://www3.lrs.lt/ pls/inter3/dokpaieska.showdoc_1?p_id=208884\&p_query=\&p_tr2=>.

3 Europos Komisijos žalioji knyga Europos skaidrumo iniciatyva [interaktyvus]. [žiūrèta 2012-10-02]. $<\mathrm{http} / /$ ec.europa.eu/transparency/eti/docs/gp_lt.pdf $>$.

4 Lobbying Disclosure Act [interaktyvus]. [žiūrèta 2012-05-18]. <http://lobbyingdisclosure.house.gov/lda. html>.

5 Šiuolaikinès lobistinès veiklos tendencijos. Mokslinè redaktorè ir sudarytoja Laima Andrikienè. Vilnius: Lietuvos teisès universitetas, 2002.

6 Geleževičius, R. Lobizmo teisinis reguliavimas ir institucionalizacija Lietuvoje: pirmojo dešimtmečio išdavos ir pamokos. Socialinių mokslu studijos. 2013, 5 (1): 177-191. 
mo technologijų, o daugiau remiasi pažintimis ir korupcija ${ }^{7},{ }^{8}$. Tą patị $2007 \mathrm{~m}$. nurodè Jurgis Vilčinskas ir Deividas Vijeikis ${ }^{9}$, o 2011 m. Alvidas Lukošaitis ${ }^{10} .2003$ m. Kreigas Edvardsas, Linas Putelis ir Viljamas Tumelis analizavo Lietuvos derybų dèl stojimo ị ES eigą, pažymėjo, kad derybų metu Lietuvos valdžios atstovai dažnai neatsižvelgdavo ị Lietuvos žemdirbių reikalavimus ${ }^{11} .2007 \mathrm{~m}$. Darius Trakelis tyrẻ BŽŪP atitikti Lietuvos žemdirbių interesams. Jo teigimu, Lietuvos žemdirbiams reikia siekti BŽŪP tęstinumo $^{12}$. 2009 m. Egle Stonkutė tyrẻ Lietuvos žemdirbių interesus ${ }^{13}$ ir žemdirbių savivaldos organizacijų atstovavimo ES institucijose tobulinimą ir siūlè, kad Lietuvos žemdirbių interesus turètų ginti viena organizacija. 2011 m. Živilès Šukytès disertacijoje teigiama, kad Lietuvos žemdirbių IG nepakankamai aktyvios, žinomos ir įtakingos, jų materialieji ir žmogiškieji ištekliai maži, o savo pozicijos jos dažnai nepagrindžia racionaliais argumentais ${ }^{14}$. Šioje disertacijoje išsamiai išnagrinèta IG veiklos ES institucijose istorija, ES politinio lygmens veikèjų įtaka formuojant BŽŪP, atstovavimo interesams modeliai, jų privalumai ir trūkumai bei Lietuvos valdžios institucijų atstovų veikla ES institucijose; tačiau autorė netyrẻ Lietuvos žemdirbių interesų, žemdirbių lobistinès veiklos metodų, privalumų, trūkumų ir rezultatų, žemdirbių konkurentų vykdant lobistinę veiklą. 2013 m. paskelbtame Švedijos mokslininkų Marko Larsono, Luisos Morin, Tomo Hano ir Johanos Sandal straipsnyje apžvelgta Lietuvos, Latvijos, Estijos ir Lenkijos žemès ūkio būklè, nurodyta, kad dẻl mažų pajamų šių šalių žemės ūkis negali naudotis pažangiomis ekologinio ūkininkavimo technologijomis ${ }^{15}$ bei teršia Baltijos jūrą kenksmingomis medžiagomis ${ }^{16}$. Autoriai teigia, kad dalis politikų palaiko ekologinio ūkininkavimo idèjas, todèl aktyvesnis lobizmas bei perèjimas prie ekologinio ūkininkavimo padètų žemdirbiams pagerinti savo padètį. Autoriai siūlo, kad Lietu-

7 Hrebenar, R.; Thomas, C. Interesu grupiu ir interesu supratimas, ju vaidmuo ir ịtaka Lietuvos valdžios politikai (tyrimo išvados). Vilnius: Mykolo Romerio universitetas, 2006.

8 Hrebenar, R. J.; McBeth, C. H.; Morgan, B. B. Interests and lobbying in Lithuania: a spectrum of development. Journal of Public Affairs. 2008, 8: 51-65.

9 Vilčinskas, J.; Vijeikis, D. Lietuvos grupių interesai Briuselyje: kelionejje be interesų grupių? Politologija. 2007, 1 (45): 95-143.

10 Lukošaitis, A. Lobizmas užsienio šalyse ir Lietuvoje: teisinio reguliavimo ir institucionalizacijos problemos. Politologija. 2011, 2 (62): 3-42.

11 Edwards, C.; Putelis, L.; Thuemmel, W. Lithuania's Accession to the European Union: Looking through the Eyes of the Lithuanian Chamber of Agriculture - What was expected to happen? What happened? Why did it happen that way? Proceedings of the 19th Annual Conference Raleigh, North Carolina. USA 212, 2003, p. 212-223.

12 Trakelis, D. Europos Sajungos bendrosios žemès ūkio politikos raidos perspektyvos ir Lietuvos interesai. Politologija. 2007, 4 (48): 87-113.

13 Tiesioginès paramos lygio skirtumai ES šalyse. Galimi tiesioginès paramos suvienodinimo scenarijai [interaktyvus]. [žiūrèta 2011-12-17]. <http://www.erpi.lt/erpi/content1.php?lg=LT\&mid=44>.

14 Šukytė, Ž. Atstovavimas nacionaliniams interesams formuojant ir igyvendinant Europos Sajungos bendrają žemès ūkio politiką: Lietuvos atvejo analizè. Daktaro disertacija. Socialiniai mokslai, politikos mokslai. Kaunas: Vytauto Didžiojo universitetas, 2011, p. 218.

15 Larsson, M.; Morin, L.; Hahn, T.; Sandahl, J. Institutional barriers to organic farming in Central and Eastern European Countries of the Baltic Sea Region. Agricultural and Food Economics. 2013, 1(5): 11.

Ibid., p. 1. 
vos, Latvijos, Estijos ir Lenkijos žemdirbiai turètų steigti ekologinių ūkių asociacijas, bei pateikia pasiūlymus, kaip šių šalių vyriausybės galètų padèti žemdirbiams ${ }^{17}$.

\section{Darbo metodai}

Šiame darbe taikomi teoriniai ir empiriniai tyrimo metodai kaip tyrimo objekto patikrinimo būdai.

Dokumentų analizè taikyta nagrinejjant 2001-2011 m. lobizmo ataskaitas, parengtas Vyriausiosios tarnybinès etikos komisijos (VTEK).

Mokslinès literatūros analizès metodas taikytas Lietuvos ir užsienio mokslinès literatūros apie lobizmą (straipsnių, darbų ir pan.) analizei, kadangi darbe siekiama kompleksiškumo bei nuoseklumo.

Lyginamuoju istoriniu metodu nurodyti žemdirbių lobistinès veiklos raidos ES ir Lietuvoje skirtumai ir palyginti bei paaiškinti žemdirbių lobistinès veiklos formavimosi ir vystymosi tendencijas ES ir Lietuvoje.

Apibendrinimo metodas taikytas naudotai mokslinei literatūrai apie lobizmą, gautiems empiriniams tyrimo duomenims, tyrimo išvadoms bei pagrindiniams tyrimo ir viso šio darbo teiginiams apibendrinti.

Kritikos metodas leido surasti žemdirbių lobistinès veiklos trūkumus, o duomenys rinkti pusiau struktūruoto interviu metodu. Anketinė apklausa buvo sukonstruota taip, kad atspindètų ịvairių interesų grupių veiklą, susijusią su Lietuvos integracija ị ES. Paveikslai ir lentelès parengti EXCEL programa.

Buvo išsiųstos 90 anketų, gauta 15 anketų (iš jų: keturios per pusiau struktūruotą interviu). Iš viso buvo išsiųstos 64 anketos, skirtos nacionalinių ir rajoninių žemdirbių organizacijų vadovams ar stambių žemės ūkių įmonių vadovams bei 26 anketos valstybės tarnautojams ir politikams, kurių veikla susijusi su žemès ūkiu.

Tyrimo metu gauti duomenys, susiję su Lietuvos IG atstovavimu ES institucijose, buvo susisteminti ir išanalizuoti. Pateiktos atlikto tyrimo išvados.

\section{Lietuvos žemdirbių lobistinė veikla}

R. Hrebenaras $2008 \mathrm{~m}$. su bendraautoriais atliko atstovavimo interesams ir lobizmo sistemos Lietuvoje tyrimą ir pateikè $2005 \mathrm{~m}$. liepos mènesi atliktos 50 Lietuvos politikų, mokslininkų, valdininkų ir žurnalistų apklausos rezultatus. Autorių nuomone, lobistinès IG bendruomenès Lietuvoje neišsivysčiusios, dažnai korumpuotos; dauguma aukščiausius postus užimančių Lietuvos politikų jas vertina neigiamai. Turinti daug ryšių ir išteklių verslo bendruomenè yra viena sẻkmingiausiai veikiančių lobistinio 
proceso dalyvių ${ }^{18}$. Po verslininkų ịtakingiausi lobistai - žemės ūkio ir kaimo plètros sektorių atstovai ${ }^{19}$.

Anot R. Hrebenaro ir bendraautorių, požiūris ị lobizmą Lietuvoje yra neigiamas, lobizmo teisinis reglamentavimas neefektyvus. Šių autorių teigimu, pagrindiniai Lietuvos lobistų metodai - korupcija ir asmeninès pažintys, todèl painiojami viešieji ir privatūs interesai. Gyventojai nelabai tiki IG politiniu efektyvumu, sieja IG veiklą su korupcija, mano, kad IG dirbtinai sukūrè komunistai. Lietuvoje trūksta daug profesionalų organizacijų, visuomenė turi per mažai žinių apie IG; taip pat gyventojai įsitikinę, kad naudingiau naudotis asmeniniais ryšiais. Lietuvoje pilietinė visuomenė silpna, dauguma gyventojų tiki, kad atskiro piliečio ar IG galimybès paveikti politinio sprendimo prièmimą ir politini procesą yra menkos. Gyventojai nesupranta, kaip prisijungimas prie IG gali pakeisti jų gyvenimą. IG taktika, turinti įtakos sprendimų prièmimui, primityvi, jos taiko draugų ir kaimynų ryšiais paremtą taktiką, tik retais atvejais IG kreipiasi ì registruotus lobistus. Geriausiai lobizmą išmano verslininkai, prasčiausiai profesinès sajungos $^{20}$.

Politologo Algio Krupavičiaus teigimu, „lietuviškoje sistemoje gausu korporatyvinès sistemos elementų. < ..> Pas mus dar iš sovietinių laikų ateina vadinamojo blato sistema, pagrịsta pažintimis ir giminystès ryšiais. Taigi protekcionizmas, despotizmas, tie suasmeninti ryšiai yra kone svarbiausias poveikio mechanizmas šiuolaikinèje Lietuvoje. <...> Tai gali pasikeisti, jeigu Lietuvos verslas, pramonè, apskritai visi ekonomikoje veikiantys asmenys labiau pradès orientuotis ị užsienio rinkas, tuomet Lietuvos verslui prireiks specifinių lobistinių paslaugų užsienyje, ES lygmeniu. Šioje vietoje ta legali lobistinė veikla būtų perspektyvesnė negu šalies viduje. Tačiau kol kas verslo ir prekybos kompanijos yra gana uždaros, $<\ldots>$ ir nesistengia daryti politinio poveikio ES sprendimams. Lietuva Briuselyje paprastai atstovaujama pačių suinteresuotų organizacijų, o ne profesionalių lobistų, kaip antai žemdirbiai“"21.

Lietuvos žemdirbiai savo interesų gynimui sukūrẻ Žemès ūkio rūmus (ŽŪR), tai yra korporatyvizmo pavyzdys. EP narès padejejejas, atsakydamas į šio magistro baigiamojo darbo autoriaus parengtos anketos valstybės tarnautojams ir politikams klausimus, nurodè, kad ŽŪR aktyviai veikia EP narius. Tačiau atsakydamos į šio magistro baigiamojo darbo autoriaus parengtos anketos darbuotojams, susijusiems su žemès ūkiu, klausimus, Lietuvos kiaulių augintojų asociacija, Lietuvos ūkininkų sajunga (LŪS), Lietuvos daržovių augintojų asociacija ir Lietuvos mokslų akademija nurodė, kad kartais gina savo interesus tiesiogiai Lietuvos ir ES institucijose. LR Prezidento patarèjas, atsakydamas ị anketos (2 priedas) klausimus, nurodè, kad ị prezidentūrą kartais tiesiogiai kreipiasi pienininkų, miško savininkų, Lietuvos žemès ūkio bendrovių asociacijos (LŽŪBA) atstovai. Tai - akivaizdūs pliuralizmo atvejai.

18 Hrebenar, R. J. et al., supra note 8, p. 51-57.

19 Ibid., p. 56.

20 Ibid., p. 51-65.

21 Trapi lobizmo ir papirkimo riba [interaktyvus]. [žiūrèta 2012-08-29]. <http://www.respublika.lt/lt/naujienos/nuomones_ir_komentarai/bus_isklausyta/trapi_lobizmo_ir_papirkimo_riba/,coments.1>. 
Klientelizmo atvejų Lietuvos žemdirbių lobistinèje veikloje šio straipsnio autoriai nepastebejo. Klientelizmas, carinès Rusijos valdymo laikais, tarpukariu ir tarybiniais laikais vyravęs Lietuvoje, beveik išnyko. Raimundo Kaminsko ir Viktorijos Marcinkevičienès teigimu, carinès Rusijos laikais ir tarpukariu Lietuvos kaimo gyventojai buvo susiskirstę i ponus, kuriuos santykinai galima ịvardinti patronais, ir kumečius, patronų klientus, už pono globą mokèjusius darbu ir lojalumu. Anot šių autorių, tarybiniais laikais atsirado blatas - artimi asmeniniai ryšiai ir neformalūs santykiai su valdančiosios komunistų partijos vadovais. Šie ryšiai suteikdavo galimybę pasiekti deficitinių išteklių šaltinius ar gauti tam tikras paslaugas (pavyzdžiui, paskyrimą i kokias nors pareigas) ${ }^{22}$. Autorių teigimu, ,klientelistinès sistemos $<\ldots>$ silpnëja tuomet, kai: a) išsenka atlygio klientams šaltiniai; b) prasideda aktyvi kova tarp patronų; c) išauga pilietinio pasitikejjimo lygis; d) silpnèja biurokratijos centralizacijos lygis“23. Iki 1990 m. Lietuvos politineje sistemoje vyravo viena politine partija, ir IG santykiai su šia partija galejo būti apibūdinti kaip klientelizmo atmaina parentela ${ }^{24}$. Po Lietuvos nepriklausomybès atkūrimo 1990 m. patronas (Lietuvos komunistų partija) prarado daug atlygio klientams šaltinių (pavyzdžiui, finansavimą iš Rusijos, daugelio pramonès įmonių bankrotas sumažino valstybès biudžeto pajamas), suskilo ị keletą tarp savęs kovojančių grupuočių, biurokratijos centralizacijos lygis susilpnèjo, pilietinio pasitikėjimo lygis irgi išaugo - atsirado žemdirbių nevyriausybinès organizacijos. Lietuvos nepriklausomybės atkūrimas ir Lietuvos komunistų partijos suirimas - pagrindinė klientelizmo sunykimo Lietuvoje priežastis.

\section{Lietuvos agrarinių organizacijų agrolobistinès veiklos tyrimas}

\section{Klausimyno ir tyrimo imties sudarymas}

Siekiant igyvendinti darbo tikslą ir uždavinius, atliktas Lietuvos žemdirbių lobizmo Lietuvos ir ES institucijose tyrimas. Šis tyrimas vykdytas 2012 m. kovo-lapkričio ménesiais. Pasirinkti respondentų atrankos kriterijai: respondento įtakingumas (ar respondentas vadovauja žemdirbių organizacijai, ar užima aukštas pareigas Lietuvos ar ES valdžios institucijose); LR nacionalinès pozicijos BŽŪP organizavimo ir ịgyvendinimo klausimais formavimo išmanymas; dalyvavimas BŽŪP formavimo ir igyvendinimo procesuose. Pagal šiuos kriterijus buvo atsirinktos šios respondentų grupės: nacionalinių ir rajoninių žemdirbių organizacijų vadovai bei valstybės tarnautojai ir politikai, susiję su žemès ūkiu. Žemdirbių organizacijų vadovams buvo sudarytas klausimynas, siekiant išsiaiškinti Lietuvos žemdirbių interesus, žemdirbių lobistinès veiklos meto-

22 Kaminskas, R.; Marcinkevičienė, V. Patrono ir kliento santykių analizė: klientelizmo sociologiniai bruožai. Mokslo taikomieji tyrimai Lietuvos kolegijose [interaktyvus]. 2009, 6: 118 [žiūrèta 2012-10-27]. <https:// ojs.kauko.lt/index.php/mttlk/article/viewFile/141/pdf_20>.

23 Ibid, p. 119.

24 Kaminskas, R. Interesų grupių ir valstybès santykiai: politikos tinklų analizès problemos. Filosofija, sociologija. 2001, 3: 28. 
dus, Lietuvos ir ES valdžios institucijas, ị kurias dažniausiai kreipiasi Lietuvos žemdirbiai, konkuruojančias žemdirbiams IG.

Valstybės tarnautojams ir politikams buvo sudarytas atitinkamas klausimynas, siekiant išsiaiškinti, kokios žemdirbių organizacijos dẻl tiesioginių išmokų suvienodinimo, žemès ūkio produkcijos gamybos reglamentavimo, žemès ūkio produkcijos supirkimo kainų padidinimo, žemès ūkio produkcijos kvotų, žemės ūkio produkcijos muitų įvedimo ES nepriklausančioms šalims, draudimo pirkti žemę Lietuvoje užsieniečiams ir kitų reikalų i juos dažniausiai kreipiasi, kokius lobizmo metodus žemdirbiai dažniausiai taiko, valstybės tarnautojų požiūrị ị šių lobizmo metodų efektyvumą ir valstybės tarnautojų nuomonę, kokiai ES ir Lietuvos institucijai žemdirbiai turètų teikti pirmenybę, gindami savo interesus. Valstybės tarnautojų ir politikų taip pat buvo klausiama, su kokių interesų grupių atstovais Lietuvos žemdirbiams tenka konkuruoti, ginant savo interesus Lietuvos ir ES institucijose.

Atrenkant respondentus, vykdyta netikimybinè tikslinė atranka ${ }^{25}$. Atsižvelgiant $\mathfrak{i}$ tyrimo objektą, buvo pasirinktos šios respondentų grupès:

1) ŽŪR nariai - 25 Lietuvos ūkininkų organizacijų vadovai; 35 žemdirbių savivaldos organizatoriai rajonuose;

2) Valstybès politikai: 10 Seimo Kaimo reikalų komiteto narių, 12 Lietuvai atstovaujančių EP narių ir 5 Regionų komiteto nariai, dirbantys su žemès ūkiu;

3) Valstybès tarnautojai: LR Prezidento patarejjai, buvę euroderybininkai, Žemès ūkio ministerijos, rajonų savivaldybių žemès ūkio skyrių darbuotojai.

Buvo atlikta žemdirbių atstovų bei valstybės tarnautojų ir politikų atsakymų dèl žemdirbių interesų, lobizmo metodų efektyvumo, prieigos taškų, žemdirbių konkurentų, vykdančių lobistinę veiklą, lyginamoji analizè. Pagal šią analizę parengtos žemdirbių lobistinès veiklos tobulinimo rekomendacijos.

İ elektroniniu paštu išsiųstą klausimyną, skirtą darbuotojams, susijusiems su žemès ūkiu, atsakė Lietuvos kiaulių augintojų asociacijos, LŪS, Lietuvos mokslų akademijos, Lietuvos daržovių augintojų asociacijos ir ŽŪR Tarptautinio skyriaus atstovai, taip pat Kèdainių ir Raseinių žemdirbių savivaldos organizatoriai. Šakių žemdirbių savivaldos organizatorius šį klausimyną užpildè raštu pokalbio metu.

Atliekant tyrimą, paaiškejo, kad lobistinejje veikloje dalyvauja nedidele Lietuvos žemdirbių dalis. Ūkininkų ūkių registro duomenimis, Lietuvoje $2012 \mathrm{~m}$. sausio $1 \mathrm{~d}$. buvo registruoti 111099 ūkininkų ūkiai ir kooperatyvai ${ }^{26}$. LŽŪBA prezidento Jeronimo Kraujelio teigimu, „ES ir valstybès paramą gauna daugiau kaip 150 tūkst. žemdirbių arba žemès valdų savininkų, tačiau žemdirbių savivaldos organizacijose formaliai dalyvauja ne daugiau kaip 10 proc. žemdirbių. <...> LŽŪBA veikloje dalyvauja 50 proc. šalyje veikiančių bendrovių. <...> Tačiau dar mažesnè ūkininkų dalis dalyvauja jų interesus aktyviai ginančių organizacijų veikloje. $<\ldots>$ Lietuvos ūkininkų sąjungoje yra apie 5000 narių, Šeimos ūkininkų sajungos vadovai tikina turintys apie

25 Degutis, M. Socialiniu tyrimu metodologija. Vilnius: Naujasis lankas, 1999, p. 57.

26 Statistinè informacija. Ūkininkų ūkių registras [interaktyvus]. [žiūrèta 2012-08-31]. <http://www.vic. $1 \mathrm{t} / \mathrm{mid}=213>$. 
4000 narių, tačiau užsiimančiųjų žemės ūkio veikla šalyje yra keliolika kartų daugiau“27. Taigi tik apie 10 proc. Lietuvos žemdirbių priklauso spaudimo grupėms.

Lietuvos kiaulių augintojų asociacija atstovauja 38 ūkiams, auginantiems kiaules, ir 9 ūkiams, neauginantiems kiaulių ${ }^{28}$. Lietuvos daržovių augintojų asociacija atstovauja 65 ūkiams, auginantiems daržoves ${ }^{29} .2010$ m. Šakių rajono ūkininkų sajungai priklausė apie 50 ūkininkų, rajone buvo per 4000 ūkininkaujančių gyventojų. Kėdainių rajone ūkininkų sajungai priklausė 20 stambių ūkininkų ${ }^{30} .2012$ m. Kėdainių krašto ūkininkų sajungai priklauso apie 135 narius $^{31} .2011 \mathrm{~m}$. Raseinių rajone buvo apie 3000 ūkininkų, LŪS Raseinių skyriaus narių - $68^{32}$.

Apibendrinant galima teigti, kad Lietuvoje yra apie 15000 žemdirbių, priklausančių lobistine veikla užsiimančioms žemdirbių organizacijoms. Tyrime dalyvavę respondentai vadovauja 5356 ūkininkams.

I kitą elektroniniu paštu išsiųsta klausimyną, skirtą valstybės tarnautojams ir politikams, atsakẻ 1 Seimo narys iš Kaimo reikalų komiteto, taip pat 1 buvęs euroderybininkas. Prezidento patarèjas ši klausimyną užpilde raštu pokalbio metu, kaip ir EP narès padèjèjas ir Panevėžio rajono savivaldybės Žemès ūkio skyriaus darbuotojas.

EP nariai ir Regionų komiteto nariai neatsakè.

Respondentų sudètis pateikta 1 paveiksle.

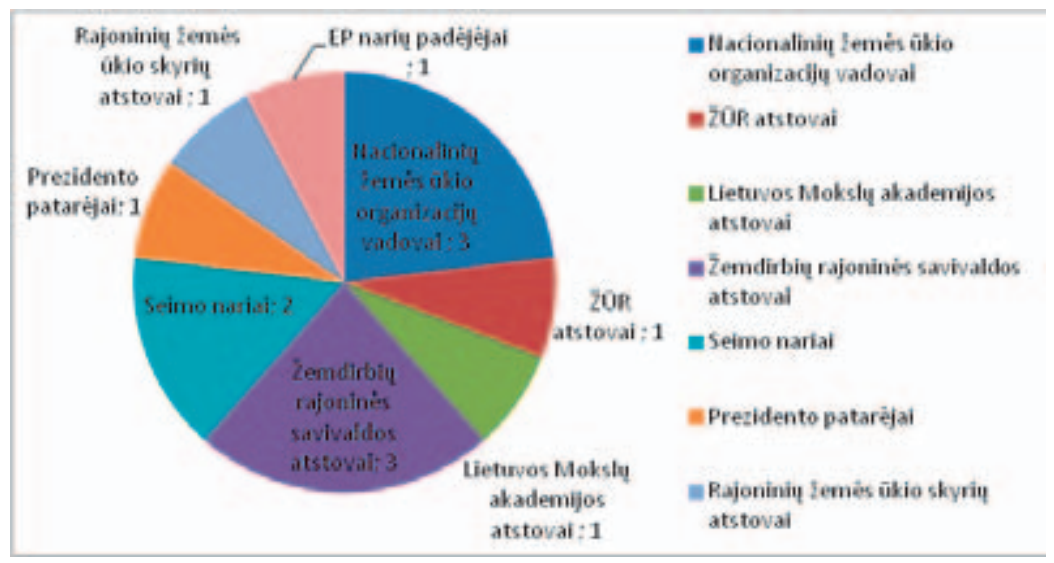

1 pav. Respondentų sudètis

27 Parama už darba, o ne už gražias akis [interaktyvus]. [žiūrèta 2012-08-31]. <http://www.kasdien.lt/Pradzia/Naujienos/Euroukis/Parama-uz-darba-o-ne-uz-grazias-akis>.

28 Lietuvos kiaulių augintojų asociacija [interaktyvus]. [žiūrèta 201208 31]. <http://www.kiaules.lt/index. php?page $=30 \&$ parent $=2>$.

29 Lietuvos daržovių augintojų asociacija [interaktyvus]. [žiūrèta 2012-08-31]. <http://www.ldaa.lt/lt/nariai>.

30 Aktyvinama Ükininku sajungos Šakiuose veikla [interaktyvus]. [žiūrèta 2012-08-31]. <http://www.drg.lt/ index.php/ukis-ir-verslas/2864-ukininkai.html>.

31 Kédainiu krašto ūkininku sajungai vadovauja tie patys ūkininkai [interaktyvus]. [žiūrèta 2012-08-31] $<\mathrm{http}: / /$ www.manoukis.lt/print_forms/print_st.php?st=14454\&m=2> .

32 LŪS Raseiniu skyriaus pirmininkas išrinktas [interaktyvus]. [žiūrèta 2012-08-31]. <http://www.alioraseiniai.lt/lus-raseiniu-skyriaus-pirmininkas-isrinktas/>. 
Iš 1 paveikslo matome, kad didžiausią ị anketos klausimus atsakiusių respondentų dalị sudaro nacionalinių žemės ūkio organizacijų atstovai ir žemdirbių rajoninės savivaldos atstovai.

\subsection{Lietuvos žemdirbių atstovų bei valstybès tarnautojų ir politiku atsakymų apie interesus ir lobistinę veiklą lyginamoji analizė}

\section{Interesu svarba}

Respondentai savo interesus pagal svarbą vertino 10 balų skalëje.

Svarbiausias Lietuvos agrarininkų interesas yra tiesioginių išmokų suvienodinimas su ES. Šị interesą 10 balų ịvertino LŪS, Lietuvos mokslų akademija, Lietuvos daržovių augintojų asociacija, ŽŪR Tarptautinis skyrius, Kėdainių ir Šakių rajonų žemdirbių asociacijų vadovai, Lietuvos kiaulių augintojų asociacija jị ịvertino 8 balais.

Svarbus yra žemès ūkio produkcijos gamybos reglamentavimas, draudimo pirkti žemę Lietuvoje užsieniečiams pratęsimas ir žemès ūkio produkcijos supirkimo kainų padidinimas. Dẻl kitų interesų svarbos ūkininkų organizacijų nuomonès išsiskiria. Tik LŪS visus 1 priedo 3 klausime nurodytus interesus laiko vienodai svarbiais ir vertina juos visus 10 balų. Kai kurios organizacijos turi vien tik joms būdingus interesus, kurie 1 priede nepateikiami. Pavyzdžiui, Lietuvos kiaulių augintojų asociacija svarbiausiu savo interesu laiko rinkos reguliavimo priemonių taikymą ( 9 balai), o Lietuvos daržovių augintojų asociacija 8 balais įvertino paramą vaisių ir daržovių augintojų organizacijoms ir grupėms bei taisyklių supaprastinimą. Mažiausiai respondentams buvo svarbus žemès ūkio produkcijos muitų įvedimas ES nepriklausančioms šalims.

Lietuvos mokslų akademijos deklaruojami interesai - tiesioginių išmokų suvienodinimas ir draudimo užsieniečiams pirkti žemę Lietuvoje pratęsimas. Šiuos interesus Lietuvos mokslų akademija laiko vienodai svarbiais ir ịvertino juos 10 balų.

ŽŪR Tarptautinis skyrius svarbiausiais Lietuvos žemdirbių interesais laiko tiesioginių išmokų suvienodinimą ir žemès ūkio produkcijos gamybos reglamentavimą (po 10 balų), 6 balais įvertino žemès ūkio produkcijos supirkimo kainų padidinimą, 3 balais - žemès ūkio produkcijos kvotas. Skyrius ypač vertina tiesioginių išmokų padidinimą, nes šias išmokas kiekvienas ūkininkas gauna besąlygiškai ir tiesiogiai. Kaimo plètra irgi svarbi, tačiau ši parama pasiekia ne kiekvieną ir jos gavimas sudètingesnis. Tiesioginių išmokų suvienodinimas būtų naudingas ne tik žemdirbiams ir kaimo gyventojams, bet ir visiems žemès ūkio produkcijos vartotojams - kiekvienam Lietuvos gyventojui.

Panašius interesus nurodo ir rajonų žemdirbių asociacijų vadovai. Kèdainių rajono Žemdirbių asociacijos nuomone, svarbiausi interesai yra tiesioginių išmokų suvienodinimas ir žemès ūkio produkcijos kainų padidinimas (10 balų). 9 balais šis respondentas įvertino žemès ūkio produkcijos muitų ịvedimą ES nepriklausančioms šalims ir draudimo pirkti žemę Lietuvoje užsieniečiams pratęsimą; 8 balais - žemès ūkio produkcijos kvotas ir žemès ūkio produkcijos reglamentavimą. Vienintelis Raseinių rajono žemdirbių asociacijos interesas - kad būtų pratęstas draudimas pirkti žemę Lietuvoje užsieniečiams. Šakių rajono žemdirbių asociacija svarbiausiais interesais laiko tiesioginių 
išmokų suvienodinimą ir draudimo pirkti žemę Lietuvoje užsieniečiams pratęsimą (10 balų), o žemès ūkio produkcijos kvotas, žemès ūkio produkcijos gamybos reglamentavimą, žemès ūkio produkcijos supirkimo kainų padidinimą ir žemès ūkio produkcijos muitų įvedimą ES nepriklausančioms šalims Šakių rajono žemdirbių asociacija įvertino 8 balais.

Su žemès ūkiu susiję 5 valstybės tarnautojai ir politikai nurodè, kad dažniausiai žemdirbiai ị valstybės tarnautojus kreipiasi dẻl tiesioginių išmokų suvienodinimo, žemès ūkio produkcijos supirkimo kainų padidinimo, draudimo pirkti žemę Lietuvoje užsieniečiams pratęsimo ir žemès ūkio produkcijos gamybos reglamentavimo. Šiuos interesus žemdirbiai laiko svarbiausiais. Tiesioginių išmokų suvienodinimą pagal kreipimųsi dažnį Prezidento patarejjas, euroderybininkas ir Panevěžio rajono Žemès ūkio skyrius įvertino 10 balų, o Seimo Kaimo reikalų komiteto narys 9 balais. Prezidento patarejo teigimu, ŽŪR pageidauja tiesiogiai skirstyti žemdirbiams valstybès ir ES paramą, kurią šiuo metu skirsto valstybė. Žemès ūkio produkcijos supirkimo kainų padidinimą 10 balų įvertino Seimo Kaimo reikalų komiteto narys, buvęs euroderybininkas ir Panevėžio rajono žemès ūkio skyrius. EP narès padejèjas svarbiausiu žemdirbių interesu nurode tiesioginių išmokų suvienodinimą ir ịvertino jị 10 balų.

\section{Lobizmo metodu efektyvumas}

Lobizmo metodus pagal efektyvumą respondentai vertino 10 balų skaleje.

Efektyviausiais lobizmo metodais respondentai (žemdirbių organizacijų vadovai) laiko viešosios nuomonès formavimo kampanijas ir ekspertų informaciją, pateikiamą susitikimuose su Lietuvos valdžios ir ES institucijų atstovais. Tai atitinka Čarlzo Lindbomo ir Edvardo Vudhauzo aprašomą tarptautinę praktiką: efektyviausia lobizmo taktika yra tiesioginiai lobistų susitikimai su valdžios atstovais, nes „profesionalus lobistas per dešimtị minučių gali paaiškinti tai, ką Kongreso narys išsiaiškintu dvi valandas pastudijavęs įstatymų projektus “333. Dèl kitų lobizmo metodų efektyvumo respondentų nuomonès išsiskiria. Jei nepavyksta savo interesų apginti naudojant viešosios nuomonès formavimo kampanijas ir ekspertu informaciją, Lietuvos žemdirbiai gali pradèti žiniasklaidos kampanijas bei sudaryti lobistines koalicijas su kitų šalių žemdirbių lobistais. Dauguma respondentų beveik nevertina elektroninio lobizmo ir ekonominio spaudimo politinėms partijoms (pavyzdžiui, pažadèti paramą rinkimų kampanijai). Tik LŪS ir ŽŪR Tarptautinis skyrius visus lobizmo metodus (išskyrus ekonominị spaudimą politinems partijoms) laiko vienodai efektyviais ir ịvertino juos 10 balų, o Lietuvos kiaulių augintojų asociacijos nuomonè apie visus lobizmo metodus kritiška. Ji efektyviausiais lobizmo metodais laiko ekspertų informaciją, spaudos (visuomenės informavimo priemonių kampanijas) bei viešosios nuomonės formavimo kampanijas, spaudžiant politinius sprendimus priimančias institucijas (6 balai). Be to, Lietuvos kiaulių augintojų asociacijos atstovas nurodé, kad kaip ekspertas dalyvauja COPA-COGECA Kiaulienos darbo grupéje.

33 Lindblom, Ch. E.; Woodhouze, E. J. Politikos formavimo procesas. Vilnius: Algarvė, 1999, p. 130131. 
3 balais Lietuvos kiaulių augintojų asociacija ịvertino lobistines koalicijas su kitų šalių žemdirbių lobistais, o 1 balu - ekonomini spaudimą politinėms partijoms ir elektroninị lobizmą.

Peržiūrejjus Vyriausiosios rinkimų komisijos interneto puslapi, paaiškejjo, kad žemdirbių organizacijos $2011 \mathrm{~m}$. neskyre pinigų politinėms partijoms, tik pavieniai žemdirbiai ar žemès ūkio bendrovès aukojo nedideles pinigų sumas ${ }^{34}$. Jie rèmė Darbo partiją, Liberalų ir centro sajungą, Lietuvos liaudies partiją, LR liberalų sajūdị, Lietuvos socialdemokratų partiją, Lietuvos valstiečių liaudininkų sajungą, Tẻvynės sajungą. Tačiau reikia pažymèti, kad 2011 m. nebuvo Seimo ir Prezidento rinkimų, vyko tik rinkimai ị savivaldybių tarybas. Ekonominio spaudimo politinèms partijoms žemdirbių organizacijos praktiškai netaiko.

Lietuvos mokslų akademija vertina tik vieną lobizmo metodą - ekspertų informaciją. Šio metodo efektyvumą Lietuvos mokslų akademija ịvertino 10 balų.

Lietuvos daržovių augintojų asociacija geriausiais lobizmo metodais laiko ekspertų informaciją, lobistines koalicijas su kitų ES šalių žemdirbiais ir viešosios nuomonès formavimo kampanijas; šiuos lobizmo metodus Lietuvos daržovių augintojų asociacija įvertino 10 balų.

ŽŪR Tarptautinis skyrius nuolat bendravo su kitų šalių žemdirbių atstovais, EK ir EP nariais ir ieškojo jų palaikymo; nemažą veiklos dalị skyrius vykdẻ kartu su kitomis dviem Baltijos valstybèmis.

Dalies rajonų žemdirbių asociacijų lobizmo metodai labai skiriasi nuo žemdirbių nacionalinių organizacijų ir ŽŪR metodų. Kèdainių ir Raseinių rajonų žemdirbių asociacijų vadovai ekspertų informacijos pateikimą valdžios atstovams laiko beprasmišku. Kèdainių rajono žemdirbių asociacija efektyviausiais savo metodais laiko spaudos (visuomenès informavimo priemonių) kampanijas bei viešosios nuomonès formavimo kampanijas (peticijas, protesto demonstracijas) (po 10 balų). Raseinių rajono žemdirbių asociacija 10 balų ịvertino spaudos (visuomenès informavimo priemonių) kampanijas, 8 balais - ekonomini spaudimą politinèms partijoms, 6 balais - viešosios nuomonès formavimo kampanijas, 5 balais - elektroninị lobizmą, 2 balais - lobistines koalicijas su kitų šalių žemdirbių lobistais. Tačiau Šakių rajono žemdirbių asociacijos lobizmo metodai panašūs į nacionalinių organizacijų ir ŽŪR lobizmo metodus: šis respondentas 10 balų ịvertino ekspertų informaciją, o 6 balais lobistines koalicijas su kitų žemdirbių lobistais ir viešosios nuomonès formavimo kampanijas.

Oficialiai registruotų lobistų Lietuvoje žemdirbių IG nesamdo. Peržiūrẻjus VTEK 2001-2011 m. lobistinès veiklos ataskaitas, žemdirbių organizacijų puslapius internete, nepavyko rasti duomenų, kad 2001-2011 m. laikotarpiu Lietuvos žemės ūkio IG savo interesų gynimui Lietuvoje būtų samdžiusios Lietuvoje registruotus lobistus. Tačiau Lietuvos kiaulių augintojų asociacija nurodè, kad Lietuvos žemès ūkio IG savo interesų gynimui Briuselyje samde Briuselyje registruotą lobistą, jo veikla buvo naudinga.

34 Politiniu partiju 2011 metu finansiniu ataskaitu rinkiniai [interaktyvus]. [žiūrèta 2012-09-02]. <http:// www.vrk.lt/lt/pirmas-puslapis/far/2011-metu-far.html>. 
Dažniausiai lobistų žemdirbiai nesamdo dèl lěšų trūkumo, nors Lietuvos kiaulių augintojų asociacijos, LŪS, Lietuvos daržovių augintojų asociacijos, Lietuvos mokslų akademijos, Kèdainių ir Šakių rajonų žemdirbių asociacijų nuomone, tokie lobistai reikalingi. Tik ŽŪR Tarptautinio skyriaus, kuris turi jame dirbančius lobistus, ir Raseinių rajono žemdirbių asociacijos nuomone, lobistų samdyti nereikia.

Atsakydamas ị klausimą apie žemdirbių lobizmo metodų efektyvumą, Prezidento patarejjas 10 balų ịvertino ekspertų informaciją, 5 balais spaudos kampanijas, 3 balais lobistines koalicijas su kitu šalių žemdirbiais, 1 balu viešosios nuomonès formavimo kampanijas. Seimo Kaimo reikalų komiteto narys 10 balų įvertino spaudos kampanijų efektyvumą, 9 balais - viešosios nuomonès formavimo kampanijas, o ekspertụ informacijos efektyvumą įvertino 8 balais. Buvęs euroderybininkas ir Panevėžio rajono Žemès ūkio skyrius efektyviu laiko tik ekspertų informacijos pateikimą. EP narès padèjejjas 10 balų ịvertino ekspertų informacijos efektyvumą, 9 balais - lobistines koalicijas su kitų šalių žemdirbių lobistais, viešosios nuomonès formavimo kampanijų ir elektroninio lobizmo efektyvumą ịvertino 8 balais.

Efektyviausiu lobizmo metodu tyrime dalyvavę valstybès tarnautojai (žemès ūkio biurokratija) laiko ekspertų informaciją, taip pat poveiki gali padaryti spaudos ir viešosios nuomonès formavimo kampanijos. Elektroninio lobizmo tyrime dalyvavę valstybės tarnautojai ir politikai, išskyrus EP narès padejejją, nevertina.

Atsakydami ị klausimą, kokius lobizmo metodus dažniausiai taiko žemdirbių atstovai, tyrime dalyvavę valstybės tarnautojai ir politikai nurode ekspertų informaciją, spaudos (visuomenès informavimo priemonių) kampanijas ir viešosios nuomonès formavimo kampanijas. Prezidento patarėjas, buvęs euroderybininkas ir Panevėžio rajono žemės ūkio skyrius teigè, kad žemdirbių atstovai pateikia tik ekspertų informaciją. Seimo Kaimo reikalų komiteto narys teigè, kad žemdirbiu atstovai naudoja ekspertų informaciją, inicijuoja spaudos kampanijas ir viešosios nuomonès formavimo kampanijas. EP narès padejjejjas nurodè ekspertų informaciją, lobistines koalicijas su kitų šalių žemdirbių lobistais ir elektroninị lobizmą.

\section{Instituciju svarbos vertinimas}

Respondentai institucijų, ị kurias turètų kreiptis žemdirbių atstovai, įtakingumą pagal svarbą vertino 10 balų skaleje.

Respondentai (žemdirbių organizacijų vadovai) dažniausiai kreipiasi į Lietuvos žemès ūkio ministeriją ir Seimą (išskyrus ŽŪR Tarptautini skyrių). LŪS Lietuvos ir ES institucijų neskirsto pagal svarbą, o savo interesus gina toje institucijoje, kurioje tuo metu yra nagrinejjamas atitinkamas klausimas. Lietuvos kiaulių augintojų asociacija pirmenybę teikia Lietuvos žemès ūkio ministerijai ( 9 balai), Seimui ( 8 balai) ir Vyriausybei ( 7 balai), retai kreipiasi ị EK (6 balai). Panaši yra Lietuvos mokslų akademijos ir Lietuvos daržovių augintojų asociacijos nuomone, tačiau Lietuvos mokslų akademija dar kreipiasi ị Lietuvos Prezidentą, o Lietuvos daržovių augintojų asociacija kreipiasi ne tik ị Lietuvos Prezidentą, bet ir ị EP. Jei nepavyksta apginti savo interesų Lietuvos 
valdžios institucijose, tada žemdirbiai kreipiasi ị EK, o rečiau ị EP. Dauguma žemdirbių organizacijoms vadovaujančių respondentų nesikreipia į ET ir Europos Teisingumo Teismą (ETT).

Kèdainių rajono žemdirbių asociacijos nuomone, geriausia kreiptis ị Žemès ūkio ministeriją (10 balų), Seimą (9 balai) ir Lietuvos Vyriausybę ( 8 balai). Panaši ir Šakių rajono žemdirbių asociacijos nuomonè: Žemės ūkio ministeriją šis respondentas ịvertino 10 balų, Seimą ir EP 8 balais. Šakių rajono žemdirbių asociacijos vadovas priklauso ŽŪR prezidiumui, tuo galima paaiškinti, kad jis kreipiasi į EP. Raseinių rajono žemdirbių asociacija kreipimąsi į Lietuvos valdžios institucijas laiko mažai efektyviu, ir įvertino ji 1 balu. Savo interesus rajonų žemdirbių asociacijos gina tiesiogiai Lietuvos valdžios institucijose ir per nacionalinę žemès ūkio asociaciją, į ES institucijas dažniausiai tiesiogiai nesikreipia.

Savo interesus Lietuvos žemdirbiai pirmiausia gina Lietuvos valdžios institucijose, taigi jų lobistinėje veikloje vyrauja nacionalinis kelias. Pirmiausia ŽŪR ir kitų žemdirbių organizacijų atstovai kreipiasi ị Lietuvos žemės ūkio ministeriją, paskui ị Seimą, Vyriausybę ir Prezidentą, jiems išdèsto savo tikslus ir interesus bei siekia Žemès ūkio ministerijos paramos ET. Žemdirbių spaudoje ir interneto puslapiuose skelbiami straipsniai, kuriuose ginami žemdirbių interesai, kartais organizuojamos protesto akcijos.

Jei nepavyksta apginti savo interesų Lietuvos valdžios institucijose, tada žemdirbiai kreipiasi į EK, o rečiau į EP. Dauguma respondentų nesikreipia į ET ir ETT. Savo narių interesus Lietuvos žemdirbių organizacijos taip pat gina per nacionalinę žemės ūkio asociaciją, per europines žemès ūkio organizacijas. Tiesiogiai ES institucijose Lietuvos žemdirbių organizacijos savo interesus gina retai. ŽŪR Tarptautinis skyrius žemdirbių interesus gina tiesiogiai Lietuvos ir ES institucijose, taip pat veikia per COPA-COGECA. Daugiausiai dėmesio ši organizacija skiria EP, kurị įvertino 10 balų, EK ( 9 balai), Lietuvos žemės ūkio ministerijai ( 8 balai) ir ET (6 balai).

Visi tyrime dalyvavę respondentai (tiek žemdirbių organizacijų vadovai, tiek su žemès ūkiu susiję valstybės tarnautojai ir politikai) įsitikinę, kad be narystės europinėse žemès ūkio organizacijose Lietuvos žemdirbiai negalès ginti savo interesų.

Tyrime dalyvavę valstybès tarnautojai ir politikai (žemės ūkio biurokratija) įtakingiausiomis institucijomis laiko EK ir Lietuvos Vyriausybę. Prezidento patarejjas EK įtakingumą ịvertino 10 balų, Lietuvos Žemès ūkio ministeriją 9 balais, Seimą 8 balais, Vyriausybę 7 balais, Prezidento, ET ir EP įtakingumą įvertino atitinkamai 6, 5 ir 4 balais. Seimo Kaimo reikalų komiteto narys įtakingiausia institucija laiko EK (10 balų), Vyriausybès, EP ir Prezidento įtaką ịvertino atitinkamai 9, 8 ir 7 balais. Buvęs euroderybininkas įtakingomis institucijomis laiko EK ir Vyriausybę, o Panevėžio rajono Žemès ūkio skyrius - Lietuvos Žemès ūkio ministeriją. EP narès padèjèjas teigia, kad didžiausia yra EP įtaka (10 balų), ET ịtaką ịvertino 9 balais, EK ịtaką -8 balais, ETT įtaką -5 balais. Jo nuomone, Lietuvos valdžios institucijos neturi jokios įtakos BŽŪP formavimui. 


\section{Žemdirbiu konkurentu vykdant lobistine veikla ịtakos vertinimas}

Respondentai žemdirbių konkurentus pagal svarbą vertino 10 balų skalèje.

Svarbiausiu konkurentu žemès ūkio organizacijoms vadovaujantys respondentai laiko žemės ūkio produkcijos perdirbejjus, kitų ES šalių žemdirbius, aplinkosaugininkus ir prekybininkus. Lietuvos laisvosios rinkos institutą, gyvūnų teisių gynejjus ir žemès ūkio produkcijos vartotojų atstovus respondentai laiko mažiau svarbiais.

Pagrindiniais konkurentais Lietuvos valdžios institucijose LŪS nurodè produkcijos perdirbejjus ir supirkejjus, o ES institucijose - kitu ES šalių žemdirbius, gaunančius didesnes tiesiogines išmokas nei ES vidurkis, ir aplinkosaugininkų organizacijas, kuriu ịtaka akivaizdžiai jaučiama EK pasiūlymuose dèl BŽŪP po 2013 m. Šiuos konkurentus LŪS laiko vienodai svarbiais ir įvertino juos 10 balų.

Lietuvos kiaulių augintojų asociacija svarbiausiais konkurentais laiko žemės ūkio produkcijos vartotojų atstovus ir kitų ES šalių žemdirbius ( 9 balai), žemės ūkio produkcijos perdirbejus ịvertino 8 balais, o gyvūnų teisių gynejjus ir aplinkosaugininkus 7 balais.

Lietuvos mokslų akademija svarbiausiu konkurentu laiko Lietuvos laisvosios rinkos institutą, ịvertino 10 balų. Prekybininkus, aplinkosaugininkus ir perdirbejjus Lietuvos mokslų akademija laiko mažiau svarbiais ir įvertino juos 9 balais.

Lietuvos daržovių augintojų asociacija svarbiausiu konkurentu laiko prekybininkus (10 balų), Lietuvos laisvosios rinkos institutą ( 8 balai), kitų ES šalių žemdirbius ivertino 7 balais, o aplinkosaugininkus 6 balais.

ŽŪR Tarptautinis skyrius svarbiausiu konkurentu laiko senųjų ES šalių žemdirbius ir įvertino juos 10 balų.

Raseinių rajono žemdirbių asociacija rimčiausiais savo konkurentais laiko žemès ūkio produkcijos perdirbejus ir aplinkosaugininkus (po 10 balų). Šakių rajono žemdirbių asociacija rimčiausiais konkurentais laiko žemès ūkio produkcijos perdirbèjus, prekybininkus ir kitų ES šalių žemdirbius.

Svarbiausiais žemdirbių konkurentais, vykdant lobistinę veiklą, tyrime dalyvavę valstybės tarnautojai ir politikai (žemès ūkio biurokratija) laiko žemès ūkio produkcijos perdirbejjus ir prekybininkus. Prezidento patarẻjas ịtakingiausiu žemdirbių konkurentu laiko žemès ūkio produkcijos perdirbejjus (10 balų), Seimo Kaimo reikalų komiteto narys su šia nuomone irgi sutinka, tačiau dar nurodè aplinkosaugininkus ( 9 balai) ir prekybininkus ( 8 balai). Buvęs euroderybininkas ịtakingais laiko žemės ūkio produkcijos perdirbejjus ir prekybininkus. Daugiausia konkurentų nurodè Panevėžio rajono žemès ūkio skyrius: žemės ūkio produkcijos perdirbejjus, vartotojų atstovus, aplinkosaugininkus ir prekybininkus; visų šių konkurentų ịtaką ịvertino 10 balų.

\subsection{Tyrimo apibendrinimas}

Žemdirbių atstovų ir su žemès ūkiu susijusių valstybės tarnautojų ir politikų nuomonès apie žemdirbių lobizmą palyginimas pateiktas lentelèje. 
Lentelè

\begin{tabular}{|c|c|c|c|}
\hline Klausimas & $\begin{array}{c}\text { Žemdirbiụ atstovų } \\
\text { atsakymas }\end{array}$ & $\begin{array}{l}\text { Su žemès ūkiu susijusių } \\
\text { valstybės tarnautojų ir } \\
\text { politikų atsakymas }\end{array}$ & \begin{tabular}{|c|} 
Žemdirbių atstovų bei \\
su žemės ūkiu susijusių \\
valstybės tarnautojų \\
ir politikų atsakymų \\
palyginimas
\end{tabular} \\
\hline $\begin{array}{l}\text { Interesų } \\
\text { svarba }\end{array}$ & $\begin{array}{l}\text { Tiesioginių išmokų suvi- } \\
\text { enodinimas } \\
\text { Draudimo pirkti žemę } \\
\text { Lietuvoje užsienie- } \\
\text { čiams pratęsimas } \\
\text { Žemès ūkio produkci- } \\
\text { jos supirkimo kainų } \\
\text { padidinimas }\end{array}$ & $\begin{array}{l}\text { Tiesioginių išmokų } \\
\text { suvienodinimas } \\
\text { Draudimo pirkti žemę } \\
\text { Lietuvoje užsieniečiams } \\
\text { pratęsimas } \\
\text { Žemès ūkio produkcijos } \\
\text { supirkimo kainų } \\
\text { padidinimas }\end{array}$ & Sutampa \\
\hline $\begin{array}{l}\text { Lobizmo } \\
\text { metodų efek- } \\
\text { tyvumas }\end{array}$ & $\begin{array}{l}\text { Viešosios nuomonės } \\
\text { formavimo kampanijos } \\
\text { Ekspertų informacija }\end{array}$ & Ekspertų informacija & $\begin{array}{l}\text { Iš dalies sutampa. } \\
\text { Valstybės tarnautojų } \\
\text { ir politikų nuomone, } \\
\text { viešosios nuomonès } \\
\text { formavimo kampanijos } \\
\text { mažai efektyvios }\end{array}$ \\
\hline $\begin{array}{l}\text { Institucijų } \\
\text { svarba }\end{array}$ & $\begin{array}{l}\text { Žemè ūkio ministerija } \\
\text { Seimas } \\
\text { Vyriausybė } \\
\text { Prezidentas }\end{array}$ & $\begin{array}{l}\text { Europos Komisija } \\
\text { Žemės ūkio ministerija } \\
\text { Seimas } \\
\text { Vyriausybė } \\
\text { Prezidentas } \\
\text { Europos Parlamentas }\end{array}$ & $\begin{array}{l}\text { Iš dalies sutampa. } \\
\text { Žemdirbių atstovų nuo- } \\
\text { mone, Lietuvos valdžios } \\
\text { institucijos turi didesnę } \\
\text { itaką formuojant BŽŪP. } \\
\text { Valstybès tarnautojų } \\
\text { ir politikų nuomone, } \\
\text { didesnę įtaką turi ES } \\
\text { institucijos }\end{array}$ \\
\hline $\begin{array}{l}\text { Konkurentų } \\
\text { ittaka }\end{array}$ & $\begin{array}{l}\text { Žemès ūkio produkci- } \\
\text { jos perdirbejai } \\
\text { Prekybininkai } \\
\text { Aplinkosaugininkai } \\
\text { Lietuvos laisvosios } \\
\text { rinkos institutas } \\
\text { Kitų ES šalių žemdirbiai }\end{array}$ & $\begin{array}{l}\text { Žemės ūkio produkcijos } \\
\text { perdirbèjai } \\
\text { Prekybininkai } \\
\text { Aplinkosaugininkai }\end{array}$ & $\begin{array}{l}\text { Iš dalies sutampa. } \\
\text { Valstybės tarnautojai ir } \\
\text { politikai Lietuvos laisvo- } \\
\text { sios rinkos institutą ir } \\
\text { kitų ES šalių žemdirbius } \\
\text { laiko neįtakingais }\end{array}$ \\
\hline
\end{tabular}

Tyrime dalyvavusių žemdirbių atstovų ir valstybės tarnautojų ir politikų (žemės ūkio biurokratijos) nuomonè dèl žemdirbių interesų beveik sutampa. Abi respondentų grupès svarbiausiais interesais laiko tiesioginių išmokų suvienodinimą ir žemės ūkio produkcijos gamybos reglamentavimą, mažiausiai svarbiu - žemès ūkio produkcijos muitu ịvedimą ES nepriklausančioms šalims.

Tyrime dalyvavusių žemdirbių atstovų ir žemès ūkio srityje dirbančiu valstybès tarnautojų bei politikų nuomonės sutampa dẻl ekspertų informacijos efektyvumo. Dèl kitų lobizmo metodų efektyvumo žemdirbių atstovų ir politikų nuomonès išsiskiria: 
valstybės tarnautojų nuomone, žemdirbiams neverta imtis elektroninio lobizmo, spaudos (visuomenès informavimo priemonių) kampanijų, viešosios nuomonės formavimo kampanijų ir sudarinèti koalicijas su kitų šalių žemdirbiais. Tačiau žemdirbiai šiuos metodus taiko ir laiko juos efektyviais, o viešosios nuomonès formavimo kampanijas laiko efektyvesnėmis už ekspertų informaciją. Taip pat galima spręsti, kad Kèdainių ir Raseinių rajonų žemdirbių asociacijų atstovai nepakankamai ịvertina ekspertų informacijos efektyvumą.

Tyrime dalyvavusių žemdirbių atstovų ir valstybės tarnautojų ir politikų (žemės ūkio biurokratijos) nuomonės sutampa tik dèl Lietuvos Vyriausybès, Prezidento ir EK svarbos. Matome, kad tyrime dalyvavusių valstybès tarnautojų ir politikų nuomone, žemdirbių atstovai pervertina Lietuvos valdžios institucijų itaką ET ir EP. Tyrime dalyvavusių valstybės tarnautojų ir politikų nuomone, geriausia būtų, kad žemdirbių atstovai savo interesus gintų EK, EP ir ET, taip pat žemdirbiai turètų samdyti profesionalius lobistus.

Tyrime dalyvavusių žemdirbių atstovų ir valstybės tarnautojų ir politikų atsakymai apie konkurentų įtaką beveik sutampa dèl žemès ūkio produkcijos perdirbejų̧, prekybininkų ir aplinkosaugininkų itakos. Tačiau valstybės tarnautojai ir politikai neįtakingais laiko Lietuvos laisvosios rinkos institutą ir kitų ES šalių žemdirbius, kuriuos žemdirbių atstovai laiko vienais iš svarbiausių konkurentų.

\section{3. Žemdirbių lobistinès veiklos rezultatai (pagal tyrimo rezultatus)}

Atsakydama ị klausimą apie lobistinès veiklos rezultatus, Lietuvos kiaulių augintojų asociacija teigia, kad pastaraisiais metais Lietuvos valstybės įstaigos demonstratyviai nebendrauja su kiauliu augintojais, o jei bendrauja, tai siunčia žemo lygio specialistus ir po susitikimų retai ịvyksta teigiamų poslinkių arba pamirštama vykdyti susitarimus, vilkinamas laikas. Sèkmingesni lobizmo atvejai, kai problema viešinama spaudoje, ir iš to kyla didesnis valdžios įstaigų noras bendradarbiauti. Sèkmè labai priklauso nuo įstaigos vadovo požiūrio ir išsilavinimo; su išmintingu vadovu viskas sekèsi, o pakeitus vadovą, nesiseka susikalbèti su visa įstaiga.

LŪS lobistinès veiklos pasiekimai Lietuvoje, žemès ūkio srityje - $2008 \mathrm{~m}$. ir $2009 \mathrm{~m}$. gautos maksimaliai leistino dydžio nacionalinès išmokos, esant stipriam ekonomikos nuosmukiui; sudarytos sąlygos ūkininkams prekiauti savo produkcija turgavietėse; supaprastintas paramos ịsisavinimas pagal kaimo plètros politikos 2007-2013 m. priemones; teisės aktais atšauktas nekilnojamojo turto mokestis kaimo vietovėse esantiems žemès ūkio asmenų gamybiniams, technologiniams, gyvenamiesiems pastatams. ES lygmeniu LŪS siekia didesnių tiesioginių išmokų Lietuvos ūkininkams, nei numatyta EK siūlymuose po $2013 \mathrm{~m}$.

Pavyzdžiui, Lietuvos daržovių augintojų asociacija pasiekè, kad būtų padidintos beakcizio dyzelino normos bulvių, daržovių pasèliams, 5 proc. sumažintas PVM tarifas daržovėms ir vaisiams, buvo priimtas mažmeninès prekybos įmonių nesąžiningų veiksmų draudimo ịstatymas, atsiskaitymo už žemès ūkio produkciją įstatymas.

ŽŪR Tarptautinis skyrius pasiekè, kad būtų priimtos Lietuvai palankios pozicijos dèl tiesioginių išmokų suvienodinimo COPA - COGECA, Regionų komitete, iš dalies Europos ekonominių ir socialinių reikalų komitete. 


\section{Valstybès finansinè parama žemdirbiu lobizmui}

Lietuvos kiaulių augintojų asociacijos lobistinei veiklai taikoma valstybės finansinè parama. Ši parama asociacijos netenkina, reikètų didesnès paramos, už kurią būtų samdomi du trys lobistai ES ịstaigose atstovauti žemès ūkiui. Specialistų rengimo ir kitos paramos Lietuvos kiaulių augintojų asociacija iš valstybės institucijų negauna. LŪS savo lobistinei veiklai gauna valstybès finansinę paramą. Specialistų rengimo ir kitos paramos iš valstybès LÜS negauna. Netiesioginè valstybès parama žemès ūkiui žemès ūkio specialistų rengimas Aleksandro Stulginskio universitete (ASU).

Lietuvos mokslų akademija iš valstybès negauna jokios paramos savo lobistinei veiklai. Lietuvos daržovių augintojų asociacija iš valstybės gauna finansinę paramą ir tos paramos asociacijai užtenka. Tačiau asociacija pageidauja valstybès paramos rengiant lobizmo specialistus.

ŽŪR Tarptautinis skyrius negauna jokios valstybès paramos. Skyrius norètų gauti finansinę valstybès paramą, kuri būtina atstovo Briuselyje išlaikymui. Valstybès paramos lobistinei veiklai Kėdainių ir Raseinių rajonų žemdirbių asociacijoms nereikia, tačiau Šakių rajono žemdirbių asociacija norètų gauti finansinę ir specialistų rengimo paramą.

Apibendrinant galima teigti, kad valstybės finansinè parama pakankama ne visoms žemdirbių organizacijoms, tačiau galbūt dalis žemdirbių valstybès finansinę paramą naudoja neefektyviai.

\section{Lietuvos žemdirbiu organizacijų lobistinès veiklos schema}

2 paveiksle pateikta dažniausiai pasitaikanti Lietuvos žemdirbių organizacijų lobizmo Lietuvos ir ES institucijose schema, sudaryta pagal šio straipsnio autorių atlikto tyrimo rezultatus.

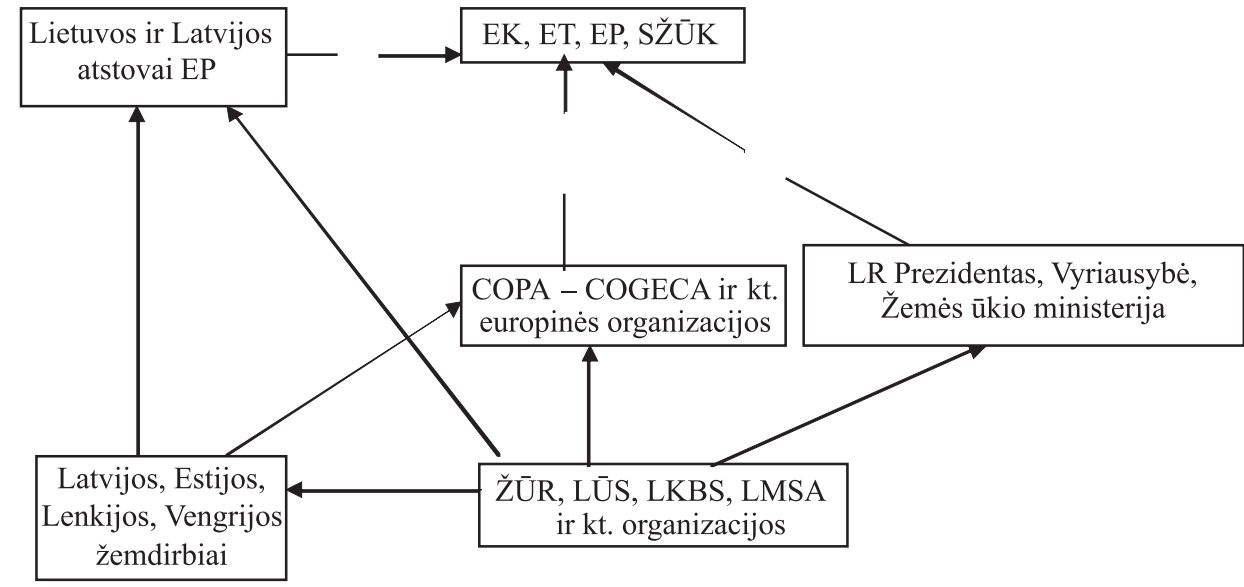

2 pav. Lietuvos žemdirbių organizacijų lobizmo Lietuvos ir ES valdžios institucijose schema (punktyrinè linija - lobistinè veikla per tarpininkus) (sudaryta autorių)

(SŽŪK - Specialus žemès ūkio komitetas, LKBS - Lietuvos kaimo bendruomenių sajunga, LMSA - Lietuvos miško savininkų asociacija) 
Iš 2 paveikslo matome, kad Lietuvos žemdirbių organizacijos dažniausiai tiesiogiai nesikreipia ị ES valdžios institucijas, o veikia per tarpininkus: Lietuvos valdžios institucijas, COPA - COGECA ir kitas europines žemdirbių organizacijas. Jei Lietuvos žemdirbiai nusprendžia kreiptis tiesiogiai ị ES institucijas, jie ieško EP narių iš Baltijos valstybių pagalbos.

\subsection{Lietuvos žemdirbių organizacijų lobistinès veiklos privalumai ir ribotumai}

Lietuvos žemdirbių lobistinės veiklos privalumai ir trūkumai apžvelgiami pagal išnagrinètą mokslinę literatūrą, žemdirbių žiniasklaidą bei tyrimo rezultatus (žemdirbių organizacijų vadovų bei su žemės ūkiu susijusių valstybės tarnautojų ir politikų apklausą).

\section{Nacionalinio kelio privalumai}

Lietuvos žemdirbių atstovai tiesiogiai susitinka su LR teisės aktų leidèjais ir visų vykdomosios valdžios lygmenų atstovais ir pateikia jiems informaciją apie savo interesus. Žemdirbiai turi savo spaudą ir interneto puslapius, kuriuose vykdo spaudos ir masinių informacijos priemonių kampanijas. Per Seimo ir savivaldybių rinkimus remiami kandidatai. Anot Živilès Šukytès, stipriausiose Lietuvos partijose yra žemdirbių atstovų, šeši iš dešimties žemès ūkio ministrų, dirbusių po nepriklausomybès atkūrimo, turejjo žemdirbio išsilavinimą, vienas buvo veterinaras. Daug žemdirbio išsilavinimą turinčių pareigūnų dirba Žemès ūkio ministerijoje ir jai pavaldžiose įstaigose bei prisideda prie Lietuvos nacionalinès pozicijos dèl BŽŬP formavimo ir jos gynimo ES lygmeniu $^{35}$. Šio straipsnio autoriaus atlikto tyrimo duomenimis, Lietuvos institucijose žemdirbiai pakankamai sėkmingai gina savo interesus, įskaitant europinius, taikydami ekspertų informacijos pateikimo valdžios institucijų atstovams metodą. Tačiau jie pervertina spaudos kampanijų ir viešosios nuomonės formavimo kampanijų efektyvumą. Taip teigia 5 apklausti valstybės tarnautojai ir politikai, kurių veikla susijusi su žemės ūkiu.

\section{Nacionalinio kelio trūkumai}

Lietuvoje, skirtingai nei kitose ES šalyse, nėra stiprios agrarinès partijos. Jiems atstovaujanti Valstiečių ir žaliųų sajunga turi tik kelias vietas Seime, didesnę ịtaką ši partija turi savivaldybése, o didžiuosiuose miestuose gauna mažai balsų. Tik tada, jei valdančiosios koalicijos ir opozicijos jègos Seime apylygès, ši partija gali pasiekti žemdirbiams naudingų sprendimų ${ }^{36}$. Lietuvos žemdirbiai nevieningi, pasyviai dalyvauja politinèje veikloje ir ŽŪR veikloje, stipriausios partijos mažai priklauso nuo žem-

35 Šukytè, Ž. Atstovavimas nacionaliniams interesams formuojant ir igyvendinant Europos Sajungos bendrają žemés ükio politiką: Lietuvos atvejo analizé. Daktaro disertacija. Socialiniai mokslai, politikos mokslai (02S). Kaunas: Vytauto Didžiojo universitetas, 2011, p. 157.

36 Radikalusis žemaitis [interaktyvus]. [žiūrèta 2012-09-02]. <http://www.veidas.lt/radikalusis-zemaitis>. 
dirbių paramos, todėl ne visada atsižvelgia ị jų interesus. Šio straipsnio autorių atlikto tyrimo duomenimis, žemdirbiai pervertina Lietuvos atstovų ịtaką BŽŪP formavimui. Taip teigia tyrime dalyvavę su žemès ūkiu susiję valstybės tarnautojai ir politikai. Be to, žemdirbių atstovams tenka konkuruoti su gyvulių teisių gynėjų, aplinkosaugininkų, Lietuvos laisvosios rinkos instituto atstovais.

\section{„Briuselio“ strategijos privalumai}

Per Lietuvos atstovus ET galima paveikti BŽŪP formavimą. Dalyvavimas COPA COGECA veikloje padeda susirasti sajungininkų tarp kitų ES valstybių narių žemdirbių ir sutaupyti lěšų, nesteigiant brangiai kainuojančių atstovybių Briuselyje.

\section{„Briuselio “ strategijos trūkumai}

Lietuvos Vyriausybès atstovai ET ne visada gali padėti Lietuvos žemdirbiams. „Mažoms valstybėms išsiderèti palankesnius ir itin svarbius ekonominius sprendimus sudètinga, nors jų argumentai svarūs. Europos Parlamento narys Gintaras Didžiokas pateikia pavyzdžių, kai išankstiniai susitarimai dẻl žemės ūkio išmokų žlugo balsavimo metu. Senujų valstybių atstovai pritaria naujujų šalių siekiams, tačiau kai prieinama prie lèšų perskirstymo, partnerystès deklaracijos pamirštamos. Pasak Žemès ūkio rūmų pirmininko Broniaus Markausko, ginant žemdirbių interesus svarbus yra šalies dydis ir bendra įtaka ES. Dažnai prieš priimant sprendimą, laukiama didžiụjų šalių pritarimo ir nuomonès. ${ }^{637}$ Dianos Panke 2009 m. atlikto tyrimo duomenimis, Lietuvos valdininkai rečiausiai iš visų ES šalių narių atstovų kreipiasi į ES institucijas dẻl savo šalies IG. Pirmenybę Lietuvos valdininkai teikia ne žemės ūkiui, o aplinkos apsaugai ir ekonomikai ${ }^{38}$. Dèl ES šalių poreikių skirtumų Lietuvos žemdirbių IG narystė COPA-COGECA ir kitose europinėse žemès ūkio interesus ginančiose organizacijose ne visada gali padèti išspręsti visas Lietuvos žemdirbių problemas ir sunkumus, su kuriais yra susiduriama. Dažnas ES šalių skirstymas į ES - 15 ir ES - 10, ir jų lyginimas parodo takoskyrą, susiformavusią tarp senujų, ypač didžiųjų, ir naujujų ES šalių. Vykstant deryboms dèl narystės, COPA-COGECA pasisakè už vienodas tiesiogines išmokas, tačiau tas pasiūlymas nebuvo priimtas dèl didžiujų valstybių įtakos ES institucijose ${ }^{39}$.

\section{Tiesioginio atstovavimo privalumai}

LŪS, LŽŪBA ir LMSA atstovai Briuselyje tiesiogiai susitinka su ES institucijų atstovais; jie nepriklauso nuo Lietuvos valdžios finansinès paramos. Sėkmingo eurolobizmo Lietuvoje pavyzdys - gauta valstybės parama ūkininkų atstovavimui tarptautinèse žemdirbių organizacijose. „Lietuvos žemdirbių organizacijoms trūksta lèšų, todèl

37 ES naujokai duoda garo [interaktyvus]. [žiūrèta 2011-12-25]. <http://www.manoukis.lt/?k=81\&m=1>.

38 Panke, D. Lobbying Institutional Key Players: How States Seek to Influence the European Commission, the Council Presidency and the European Parliament. Journal of Common Market Studie. 2012, 50 (1): 133.

39 Lietuvos Respublikos žemès ūkio ministerija, diskusijos [interaktyvus]. [žiūrèta 2012-01-07]. <http:// www.zum.1t/min/Spauda/files/Zemes_ukio_ministerija_20051217.htm\#415430>. 
jų atstovavimas tarptautinėse žemdirbių organizacijose yra remiamas nacionalinio biudžeto lěšomis. Apie trečdalis visų žemdirbių organizacijoms skiriamų lëšų yra skiriama kaip parama dalyvauti tarptautinių organizacijų veikloje. Ši suma kasmet didejja. 2005 m. ji sudarè 823 tūkst. Lt, o 2008 m. ji <...> siekè 1231 tūkst. Lt. Daugiau nei pusẻ visos šios sumos yra skiriama žemdirbių organizacijų atstovavimui COPA-COGECA organizacijoje. “" ${ }^{“ 40}$ Šio straipsnio autorių atlikto tyrimo duomenimis, žemdirbių atstovai gali pakankamai sèkmingai ginti savo interesus EK, taikydami ekspertų informacijos pateikimo metodą. Tyrime dalyvavę su žemès ūkiu susiję valstybės tarnautojai ir politikai teigia, kad ekspertų informacija - efektyviausias žemdirbių lobizmo metodas.

\section{Tiesioginio atstovavimo trūkumai}

Šio straipsnio autorių atlikto tyrimo duomenimis, Lietuvos žemdirbių interesus ginančios organizacijos šiuo metu negali tinkamai atstovauti savo narių interesų ES institucijose. Joms trūksta lobistinès veiklos patirties, jos dažnai veikia atskirai. Be to, žemdirbių atstovai nepakankamai vertina ES institucijų įtaką formuojant BŽŪP, ir tiesiogiai i jas nesikreipia; jie dažniau pirmenybę teikia Lietuvos valdžios institucijoms. Tyrime dalyvavusių su žemės ūkiu susijusių valstybės tarnautojų ir politikų nuomone, žemdirbiai pirmiausia turètų kreiptis ị ES institucijas.

\section{Nesutarimai su Lietuvos valdžios institucijomis}

Savo interesus ginti žemdirbiams kartais trukdo nesutarimai su Lietuvos valdžios institucijomis. Iki Lietuvos ịstojimo ị ES žemdirbių santykiai su Lietuvos valdžios institucijomis buvo ypač prasti, ir žemdirbiai kèle prieš Lietuvą bylas Europos Žmogaus Teisių Teisme, Strasbūre. 2001 m. 11500 Lietuvos žemdirbių kreipèsi ị Europos Žmogaus Teisių Teismą dèl to, „,kad Žemès ūkio ministerija 1999 metais pusę metų jiems nemokèjo valstybès subsidijų už maisto perdirbimo įmonèms parduotus grūdus, pieną ar mèsą. < ..> Pirmasis sąraše buvo ịrašytas Biržų ūkininkas Kazys Visockas, todèl byla buvo vadinama pagal jo pavardę. Tačiau tikrasis ūkininkų skundo iniciatorius - buvęs Seimo narys Ramūnas Karbauskis. Kai buvo renkami parašai, jis žadèjo padengti visas teismo išlaidas. < ...> Išnagrinėjęs žemdirbių pareiškimą bei Lietuvos Vyriausybės pateiktą poziciją Žmogaus Teisių Teismas nusprendè, kad pareiškejjai nepanaudojo visų teisinių gynybos priemonių, ir paskelbẻ šią skundo dali nepagrịsta“441. $2008 \mathrm{~m}$. ūkininkai Arūnas Kudrevičius, Kęstutis Miliauskas, Virginijus Mykolaitis, Artūras Pilota ir ŽŪR pirmininkas Bronius Markauskas, nuteisti už 2003 m. vykdytą kelių blokadą (taip buvo protestuojama prieš mažas žemès ūkio produkcijos supirkimo kainas), pateikẻ Europos Žmogaus Teisių Teismui skundą prieš Lietuvą, teigdami, kad Vyriausybė

40 Labutienè, E. Žemdirbiu savivaldos organizaciju atstovavimo ES institucijose tobulinimas. Galutinè 2008 m. tyrimo ataskaita [interaktyvus]. Vilnius: 2008, p. 27 [žiūrèta 2011-12-18]. <http://www.zum.lt/lt/ zemes-ukio-ministerija/mokslas--mokymas-ir-konsultavimas/mokslo-ir-mokymo-skyriaus-skelbiama-informacija/zemdirbiu-savivaldos-organizaciju-atstovavimo-es-institucijose-tobulinimas/>.

41 Strasbūras atmetè Lietuvos ükininku skunda [interaktyvus]. [žiūrèta 2012-06-03]. <http://verslas.delfi.lt/ business/strasburas-atmete-lietuvos-ukininku-skunda.d?id=8461858>. 
pažeidè jų ,teisę i teisingą bylos nagrinèjimą, saviraiškos, susirinkimų ir asociacijos laisvę, teisę ị nuosavybés apsaugą “42. Apie bylos baigtị duomenų rasti nepavyko.

\subsection{Lietuvos žemdirbių organizacijų lobistinès veiklos tobulinimo gairès ir perspektyvos}

Siekiant ịgyti didesnę įtaką sprendimų priėmimui ir sėkmingiau vykdyti lobistinę veiklą, visiems Lietuvos žemdirbiams turi atstovauti viena skètinė organizacija, nes tik tokiu būdu galima užtikrinti atitinkamą savivaldos organizacijų atliekamo vaidmens ịvertinimą ir sustiprinti jų reikšmingumą visame sprendimų prièmimo procese ${ }^{43}$.

Be to, Lietuvos žemdirbių organizacijoms reikia ieškoti sajungininkų kitose ES šalyse. Dideli šalių skirtumai ir jau susiformavęs poreikių atotrūkis skatina pavienes šalis jungtis i sajungas, formuoti bendras pozicijas ir jas tiesiogiai reikšti ES institucijoms. Vienas tokių pavyzdžių - Baltijos šalių žemès ūkio organizacijų taryba ${ }^{44}$. Panašios klimatinės sąlygos, istoriniai aspektai, vis dar stipriai veikiantys šalių raidą, leidžia surasti daug bendrų problemų ${ }^{45}$. Visa tai, ką Baltijos šalims pavyko pasiekti BŽŪP pokyčių srityje, buvo įmanoma tik laikantis bendros pozicijos, kurią dažniausiai palaikè Lenkija $^{46}$. Taip pat Lietuvos žemdirbius galètų palaikyti kitų ES šalių ūkininkai, kuriems naudingas tiesioginių ES išmokų suvienodinimas: ispanai, portugalai, rumunai, bulgarai ir kiti.

Šio straipsnio autorių atlikto tyrimo duomenimis, Lietuvos agrarinès IG linkusios savo poziciją ES institucijose ginti su Lietuvos valdžios atstovų pagalba. Tai galima laikyti teisingu sprendimu, nes lobistinès firmos „Burson-Marsteller“ duomenimis, ES institucijos, ypač EK ir ET, labiausiai atsižvelgia į ES valstybių narių vyriausybių nuomonę ${ }^{47}$.

Lietuvos agrarinès IG iš visų lobizmo metodų labiausiai vertina ekspertų informaciją, kuri ypač naudinga kreipiantis į EK. Tačiau Lietuvos agrarinès IG retai kreipiasi tiesiogiai i ES institucijas. Dalis apklaustų žemdirbių atstovų IG mažai vertina lobizmo metodus, kurie naudingi veikiant EK, EP ir ET. Dalis respondentų skeptiškai vertino spaudos kampanijų efektyvumą. Tačiau lobistinės firmos „Burson-Marsteller“ $2005 \mathrm{~m}$. atlikto tyrimo duomenimis, ES institucijas galima paveikti rengiant spaudos kampanijas, rašant straipsnius ị tokius leidinius, kaip „Financial Times“, „Economist“,

42 Kelius blokavę ükininkai Strasbūre kovoja prieš Lietuva [interaktyvus]. [žiūrèta 2012-06-03]. <http:// www.mediabv.lt/res_zinpr_det.php?id=20482>.

43 LUSS surengtoje tarptautinèje konferencijoje - apie naujuju ES šaliu nariu žemdirbiu vieninguma ir galimybes daryti ịtaka bendrajai žemès ūkio politikai [interaktyvus]. [žiūrèta 2011-12-21]. <http://www.zur.lt/ index.php?1139556284>.

$44 \quad$ Supra note 37.

45 LUUS surengtoje tarptautineje konferencijoje - apie naujuju ES šaliu nariu žemdirbiu vieninguma ir galimybes daryti ịtaka bendrajai žemès ükio politikai [interaktyvus]. [žiūrèta 2011-12-21]. <http://www.zur.lt/ index.php?1139556284>.

46 Supra note 37.

47 The Definitive Guide to Lobbying the European Institutions [interaktyvus]. [žiūrèta 2012-06-01]. <http:// www.eapn.ie/eapn/wp-content/uploads/2009/10/definitive-guide-to-lobbying-eu-institutions-training. pdf $>$. 
„Le Monde“, „Der Spiegel“, „Wall Street Journal“, „Economist“, „International Herald Tribune“, „El Pais“. EP nariai ir ET darbuotojai atsižvelgia ị straipsnius nacionalinèje žiniasklaidoje. Tačiau EK nariai straipsnius nacionalinèje žiniasklaidoje vertina mažiau nei straipsnius „Financial Times“ ir panašiuose leidiniuose. Labai efektyvūs gali būti straipsniai Briuselio savaitraštyje „European Voice“. Daug naudos gali duoti BBC ir CNN televizijų laidos ir interneto puslapiai ${ }^{48}$. Spaudos kampanijų naudą pripažįsta ir Kęstutis Jaskelevičius, kaip pavyzdị pateikdamas vieno iš žemdirbių konkurento - Lietuvos laisvosios rinkos instituto veiksmus. Anot Kęstučio Jaskelevičiaus, šio instituto atstovai žiniasklaidos priemonėse reiškia nuomonę visais aktualiais ekonominiais ir socialiniais klausimais ${ }^{49}$, prieš Seimo rinkimus leidžia Seimo nariams ir rinkejjams skirtas knygas, kurias Seimo nariai gauna veltui, prasidèjus kadencijai ${ }^{50}$.

Siekiant išsiaiškinti, ar Lietuvos žemdirbiai turi bendrų interesų su žemės ūkio mokslininkais ir ar vykdo lobistinę veiklą kartu su jais, papildomai buvo apklausti 2 ASU darbuotojai. Sprendžiant iš šių respondentų atsakymų, ASU neturi su žemdirbiais bendrų lobistinių interesų (vienintelis šio universiteto interesas - mokslo projektai), ir bendros lobistinès veiklos su jais nevykdo, todèl ì 1 paveiksle parodytą respondentu sudètị šių respondentų atsakymai neįtraukti. Tai, kad Lietuvos žemdirbiai nepalaiko ryšių su šiuo universitetu, galima laikyti jų lobistinès veiklos trūkumu, nes ASU lobistinė veikla gana sèkminga. Šio universiteto atstovai, kartu su kolegomis iš Vokietijos, Prancūzijos, Lenkijos ir Vengrijos samdè lobistus Briuselyje, kreipèsi ị EK ir 2005-2007 m. gavo finansavimą 6 - osios Bendrosios programos projektui. Jeigu Lietuvos žemdirbiai i̊stengtų rasti bendrų interesų su šiuo universitetu, pavyzdžiui, remtų jo mokslo projektus, ir derintų savo lobistinę veiklą su juo, galima tikètis, kad jiems lengviau būtų rasti prieigos taškus Briuselyje.

Galimas Lietuvos žemdirbių sajungininkas vykdant lobistinę veiklą yra Europos regioninès plètros institutas. Šis institutas skiria daugiausia dèmesio žemès, maisto ir žuvų sektoriaus problemoms, bei pripažista, kad ES dažnai ignoruoja naujai įstojusių šalių interesus ir proteguoja senąsias ES valstybes nares. Taip pat šis institutas palaiko Lietuvos žemdirbių siekị dèl tiesioginių išmokų suvienodinimo ${ }^{51}$. Tačiau tyrimo metu nerasta jokių duomenų apie Lietuvos žemdirbių ir Europos regioninès plètros instituto bendradarbiavimą vykdant lobistinę veiklą.

Švedijos mokslininkai, apklausę Lietuvos, Latvijos, Estijos ir Lenkijos žemdirbių organizacijų vadovus, mokslininkus, valstybès tarnautojus apie finansinę paramą žemdirbiams, ịstatymus, rinką, produkciją, visuomenès procesus, infrastruktūrą ${ }^{52}$ 2013 m. irgi pateikè pasiūlymų, kaip Lietuvos, Latvijos, Estijos ir Lenkijos žemdirbiai galètų tobulinti savo lobistinę veiklą. Šių mokslininkų teigimu, Lietuvos, Latvijos,

48 The Definitive Guide to Lobbying the European Institutions, supra note 47.

49 Jaskelevičius, K. Valstybès atèmimas. Politika. Ekonomika. Kaimas. Miškai. Vilnius: Petro ofsetas, 2010, p. 521-522.

$50 \quad$ Ibid., p. 523.

51 „Slènis Nemunas“ ir europiniai procesai [interaktyvus]. [žiūrèta 2012-10-28]. <http://mokslasplius.lt/ mokslo-lietuva/2012/2012/03/\%E2\%80\%9Eslenis-nemunas-ir-europiniai-procesai/>. 
Estijos ir Lenkijos žemės ūkis yra vienas pagrindinių Baltijos jūros teršèjų ${ }^{53}$. Todèl šie mokslininkai siūlo Lietuvos, Latvijos, Estijos ir Lenkijos žemdirbiams pereiti prie ekologinio ūkininkavimo, steigti ekologinių ūkių savininkų organizacijas ir tada kreiptis paramos ị savo šalių ir ES institucijas ${ }^{54}$. Šių mokslininkų teigimu, tada Lietuvos, Latvijos, Estijos ir Lenkijos žemdirbiams būtų lengviau gauti finansinę paramą, nes dalis politikų palaiko ekologinị ūkininkavimą. Be to, tada žemdirbius paremtų ir aplinkos apsaugos organizacijos.

Lietuvos žemdirbiai, siekdami sèkmingiau vykdyti lobistinę veiklą, turètų dažniau tiesiogiai kreiptis ị ES institucijas, glaudžiau bendradarbiauti su panašius interesus turinčiomis žemdirbių organizacijomis iš kitų ES šalių, ir su Lietuvos valdžios institucijomis, kartu kurti lobistinès veiklos idejas ir praktiškai jas igyvendinti. Taip pat siekti mokslininkų, dirbančių žemès ūkio srityje, paramos, bei dažniau tiesiogiai kreiptis ị ES institucijas bei samdyti profesionalius lobistus. Žemdirbių organizacijos turètų vykdyti ekonominį spaudimą politinėms partijoms - siūlyti partijoms finansinę paramą rinkimų kampanijoms ir finansuoti žemdirbiams palankių partijų ir politikų Seimo ir EP rinkimų kampanijas. Tai padètų užtikrinti palankesnị partijų požiūrị ị žemdirbių interesus.

\section{Išvados}

1. BŽŪP formuoja ES valstybių narių žemės ūkio ministrai, EK žemės ūkio pareigūnai ir Europos žemdirbių interesų atstovai. Žemès ūkio taryba, sudaryta iš ES valstybių narių žemés ūkio ministrų, yra centrinė sprendžiamoji institucija, EK vykdo šios Tarybos priimtus sprendimus. Tyrime dalyvavę valstybės tarnautojai ir politikai, susiję su žemès ūkiu, nurodè, kad BŽŪP formavime įtakingiausi yra EK ir nacionalinių žemès ūkio ministerijų atstovai.

Didžiausią įtaką formuojant Lietuvos žemdirbių poziciją dèl BŽŪP turi ŽŪR ir nacionalinių žemdirbių organizacijų vadovai, kurie planuoja, vykdo ir igyvendina lobistinę veiklą Lietuvoje ir Briuselyje. ES institucijose Lietuvos žemdirbių lobizmas dar silpnas, tačiau jie moka formuluoti ir ginti savo pozicijas. Lietuvos žemdirbių organizacijos, išskyrus LMSA, nesiregistruoja ES Skaidrumo registre. Profesionalių lobistų žemdirbiai dažniausiai nesamdo. Pagrindiniai žemdirbių atstovų lobizmo metodai ekspertų informacija ir viešosios nuomonès formavimo kampanijos. Lietuvos žemdirbių lobistinè veikla turi korporatyvizmo ir pliuralizmo bruožų, tačiau korporatyvizmo bruožų yra daugiau.

2. Dažniausiai žemdirbių atstovai kreipiasi į Lietuvos valdžios institucijas, į ES institucijas žemdirbių atstovai kreipiasi per tarpininkus - Lietuvos valdžios institucijų atstovus ar per europines žemdirbių organizacijas. Tiesiogiai ị ES institucijas Lietuvos žemdirbiai kreipiasi retai, o kada i jas kreipiasi, tai pirmenybę teikia EP nariams iš Baltijos valstybių. Lietuvos žemdirbiams trūksta lobizmo ịūdžių: tik 10 proc. Lietu-

53 Larsson, M. et al., supra note 15, p. 1-2.

54 Ibid., p. 16. 
vos žemdirbių dalyvauja žemdirbių organizacijų veikloje, ne visada taikomi tinkami lobizmo metodai, pavyzdžiui, nepakankamai įvertinama spaudos kampanijų reikšmé ES institucijų sprendimams, be to, Lietuvos žemdirbiai klysta, manydami, kad Lietuvos valdžios institucijos turi didesnę įtaką BŽŪP nei ES institucijos. Svarbiausio tikslo -tiesioginių išmokų suvienodinimo, Lietuvos žemdirbiams dar nepavyko pasiekti. Su Lietuvos žemdirbiais konkuruojančios anksčiau į ES įstojusių valstybių žemdirbių IG sėkmingiau gina savo interesus ES institucijose, nes turi ilgalaikes lobizmo tradicijas savo šalyse.

3. Lietuvos žemdirbiams reikètų formuoti lobistines koalicijas su kitų ES valstybių žemdirbių IG, turinčiomis panašių interesų. Taip pat Lietuvos žemdirbiams reikètų ieškoti sajungininkų tarp aplinkos apsaugos organizacijų, siūlant ekologinio ūkininkavimo projektus. Tokiu atveju Lietuvos žemdirbių interesus palaikytų ir ekologini ūkininkavimą bei aplinkos apsaugą remiantys politikai. Be sajungininkų Lietuvos žemdirbiams bus sunku ginti savo interesus ES institucijose, nes šiose institucijose Lietuvos žemdirbių IG mažai kam žinomos, ir turi mažai narių ir materialinių išteklių.

\section{Literatūra}

Aktyvinama Ūkininku sajungos Šakiuose veikla [interaktyvus]. [žiūrèta 2012-08-31]. <http:// www.drg.lt/index.php/ukis-ir-verslas/2864ukininkai.html>.

Degutis, M. Socialiniu tyrimu metodologija. Vilnius: Naujasis lankas, 1999.

Edwards, C.; Putelis, L.; Thuemmel, W. Lithuania's Accession to the European Union: Looking through the Eyes of the Lithuanian Chamber of Agriculture-What was expected to happen? What happened? Why did it happen that way? Proceedings of the 19th Annual Conference Raleigh, North Carolina, USA 212, 2003, p. 212-223.

EK žalioji knyga Europos skaidrumo iniciatyva [interaktyvus]. [žiūrèta 2012-10-02]. $<$ http://ec.europa.eu/transparency/eti/docs/ gp_lt.pdf $>$.

ES naujokai duoda garo [interaktyvus]. [žiūrèta 2011-12-25]. <http://www.manoukis. $1 \mathrm{t} / ? \mathrm{k}=81 \& \mathrm{~m}=1>$.

Geleževičius, R. Lobizmo teisinis reguliavimas ir institucionalizacija Lietuvoje: pirmojo dešimtmečio išdavos ir pamokos. Socialiniu mokslų studijos. 20135 (1): 177-191.
Hrebenar, R. J.; McBeth, C. H.; Morgan, B. B. Interests and lobbying in Lithuania: a spectrum of development. Journal of Public Affairs. 2008, 8: 51-65.

Hrebenar, R.; Thomas, C. Interesu grupiu ir interesu supratimas, ju vaidmuo ir ịtaka Lietuvos valdžios politikai (tyrimo išvados). Vilnius: Mykolo Romerio universitetas, 2006.

Jaskelevičius K., Valstybès atèmimas. Politika. Ekonomika. Kaimas. Miškai. Vilnius: Petro ofsetas, 2010.

Kaminskas, R. Interesų grupių ir valstybès santykiai: politikos tinklų analizès problemos. Filosofija, sociologija. 2001, 3: 20-30.

Kaminskas, R.; Marcinkevičienė, V. Patrono ir kliento santykių analizè: klientelizmo sociologiniai bruožai. Mokslo taikomieji tyrimai Lietuvos kolegijose. 2009, 6: 115-121.

Kèdainiu krašto ūkininku sajungai vadovauja tie patys ūkininkai [interaktyvus]. [žiūrèta 2012-08-31].<http:/www.manoukis.lt/ print_forms/print_st.php?st=14454\&m=2>.

Kelius blokavę ūkininkai Strasbūre kovoja prieš Lietuva [interaktyvus]. [žiūrèta 2012-0603]. <http://www.mediabv.lt/res_zinpr_det. php?id=20482 $>$. 
Labutienè, E. Žemdirbiu savivaldos organizaciju atstovavimo ES institucijose tobulinimas. Galutine 2008 m. tyrimo ataskaita [interaktyvus]. [žiūrèta 2011-12-18]. <http://www. zum.lt/lt/zemes-ukio-ministerija/mokslas-mokymas-ir-konsultavimas/mokslo-irmokymo-skyriaus-skelbiama-informacija/ zemdirbiu-savivaldos-organizaciju-atstovavimo-es-institucijose-tobulinimas/>.

Larsson, M.; Morin, L.; Hahn, T.; Sandahl, J. Institutional barriers to organic farming in Central and Eastern European Countries of the Baltic Sea Region. Agricultural and Food Economics. 2013, 1(5): 1-20.

Lietuvos daržoviu augintoju asociacija. [interaktyvus]. [žiūrèta 201208 31].<http:// www.ldaa.lt/lt/nariai $>$

Lietuvos kiauliu augintoju asociacija. [interaktyvus]. [žiūrèta 201208 31]. <http://www. kiaules.1t/index.php?page $=30 \&$ parent $=2>$

Lietuvos Respublikos lobistinès veiklos įstatymas [interaktyvus]. [žiūrèta 2012-05-18]. $<$ http://www3.lrs.lt/pls/inter3/dokpaieska. showdoc_1?p_id=208884\&p_query=\&p_ tr2 $=>$.

Lietuvos Respublikos žemès ūkio ministerija, diskusijos [interaktyvus]. [žiūrèta 201201-07]. <http://www.zum.lt/min/Spauda/ files/Zemes_ukio_ministerija_20051217. htm\#415430>

Lindblom, Ch. E.; Woodhouze, E. J. Politikos formavimo procesas. Vilnius: Algarvè, 1999.

Lobbying Disclosure Act [interaktyvus]. [žiūrèta 2012-05-18]. <http://lobbyingdisclosure. house.gov/lda.html>.

Lukošaitis, A. Interesų grupès Lietuvoje: raidos dinamika ir institucionalizacijos bruožai. Politologija. 2000, 2 (18): 85-114.

Lukošaitis, A. Lobizmas užsienio šalyse ir Lietuvoje: teisinio reguliavimo ir institucionalizacijos problemos. Politologija. 2011, 2 (62): 3-42.

LŪS Raseiniu skyriaus pirmininkas išrinktas [interaktyvus]. [žiūrèta 2012-08-31]. <http:// www.alioraseiniai.lt/lus-raseiniu-skyriauspirmininkas-isrinktas/>.
LUSS surengtoje tarptautineje konferencijoje apie naujuju ES šaliu nariu žemdirbiu vieninguma ir galimybes daryti ịtaka bendrajai žemés ükio politikai [interaktyvus]. [žiūrèta 2011-12-21]. <http://www.zur.lt/index. php?1139556284>.

Panke, D. Lobbying Institutional Key Players: How States Seek to Influence the European Commission, the Council Presidency and the European Parliament. Journal of Common Market Studies. 2012, 50 (1): 129-150.

Parama už darbą, o ne už gražias akis [interaktyvus]. [žiūrèta 201208 31]. <http://www. kasdien.lt/Pradzia/Naujienos/Euroukis/Parama-uz-darba-o-ne-uz-grazias-akis $>$

Politiniu partiju 2011 metu finansiniu ataskaitu rinkiniai [interaktyvus]. [žiūrèta 2012-0902]. <http://www.vrk.lt/lt/pirmas-puslapis/ far/2011-metu-far.html>.

Radikalusis žemaitis [interaktyvus]. [žiūrèta 2012-09-02]. <http://www.veidas.lt/radikalusis-zemaitis>.

„Slènis Nemunas “ ir europiniai procesai [interaktyvus]. [žiūrèta 2012-10-28]. <http:// mokslasplius.lt/mokslo-lietuva/2012/2012/ 03/\%E2\%80\%9Eslenis-nemunas-ir-europiniai-procesai/>.

Statistine informacija. Ūkininku ūkiu registras [interaktyvus]. [žiūrèta 2012-08-31]. <http:// www.vic.lt/?mid=213>.

Strasbūras atmete Lietuvos ūkininku skunda [interaktyvus]. [žiūrèta 2012-06-03]. <http:// verslas.delfi.lt/business/strasburas-atmetelietuvos-ukininku-skunda.d?id=8461858>.

Šiuolaikinès lobistinès veiklos tendencijos. Mokslinè redaktorè ir sudarytoja Laima Andrikienè. Vilnius: Lietuvos teisès universitetas, 2002.

Šukytè, Ž. Atstovavimas nacionaliniams interesams formuojant ir igyvendinant Europos Sajungos bendrają žemès ūkio politiką: Lietuvos atvejo analizè. Daktaro disertacija. Socialiniai mokslai, politikos mokslai (02S). Kaunas: Vytauto Didžiojo universitetas, 2011.

The Definitive Guide to Lobbying the European Institutions [interaktyvus]. [žiūrèta 2012- 
06-01]. <http://www.eapn.ie/eapn/wpcontent/uploads/2009/10/definitive-guideto-lobbying-eu-institutions-training.pdf $>$.

Tiesioginès paramos lygio skirtumai ES šalyse.

Galimi tiesiogines paramos suvienodinimo scenarijai [interaktyvus]. [žiūrèta 201112-17]. <http://www.erpi.lt/erpi/content1. php?lg=LT\&mid $=44>$.

Trakelis, D. Europos Sajungos bendrosios žemès ūkio politikos raidos perspektyvos ir Lietuvos interesai. Politologija. 2007, 4 (48): 87-113.
Trapi lobizmo ir papirkimo riba.[interaktyvus] [žiūrèta 2012-08-29]. <http://www.respublika.lt/lt/naujienos/nuomones_ir_komentarai/ bus_isklausyta/trapi_lobizmo_ir_papirkimo_riba/,coments. $1>$.

Vilčinskas, J.; Vijeikis, D. Lietuvos grupių interesai Briuselyje: kelioneje be interesu grupių? Politologija. 2007, 1 (45): 95-143.

ŽŨR prezidiumo rezoliucija „, Dèl bendrosios žemès ükio politikos po $2013 \mathrm{~m}$." [interaktyvus]. [žiūrèta 2011-12 -13]. <http://www. zur.lt/index.php?-1190738131>.

\title{
AGROLOBBYISM IN EU AND LITHUANIA
}

\author{
Vygandas Paulikas, Linas Jonas Gustas \\ Mykolas Romeris University, Lithuania
}

Summary. Lobbying activities of Lithuanian agricultural interest groups in European and Lithuanian institutions are described in this paper. Lobbying activities of Lithuanian agricultural interest groups have elements of pluralism and corporatism, but elements of corporatism are more numerous. Also, this paper touches upon lobbying activities in the European Commision, the European Parliament and the European Council. Leaders of Lithuanian agricultural interest groups and Lithuanian statesmen were interviewed about interests, lobbyism method effectiveness, access points of Lithuanian agricultural groups and of competitive interest groups. A comparative analysis of the answers of the Lithuanian agricultural group leaders and the Lithuanian statesmen was made. The paper presents conclusions of the above analysis.

Lithuanian state officials and politicians which took part in the research interviews stated that the most influential Common Agriculture Policy formers are officials of European Commision and officials of national agricultural ministries.

The most influential shapers of Lithuanian farmers' position are top officials in the Chamber of Agriculture of the Republic of Lithuania and leaders of national farmers' organisations. They plan and execute lobbying activities in Lithuania and Brussels. Lithuanian farmers' lobbying activities in European Union institutions is weak, but Lithuanian farmers are able to form their position and to defend it. Lithuanian agricultural organisations, except Lithuanian Forest Owners Association, are not registered in European Union Transparency Register. Lithuanian agricultural organisations do not hire professional lobbyists in most cases. The basic methods of Lithuanian farmers' lobbying activities are expert information and campaigns of public opinion forming.

In most cases Lithuanian farmers' leaders appeal to Lithuanian government institutions. To European Union institutions Lithuanian farmers appeal through mediators. Those 
mediators are Lithuanian state officials or European agricultural organisations. Lithuanian farmers rarely appeal to European Union institutions directly. In cases of direct address of EU institutionsLithuanian farmers ask for assistance of the European Parliament members from the Baltic States. Lithuanian farmers lack lobbying abilities. Only 10 percent of Lithuanian farmers participate in activities of agricultural organisations. Lithuanian farmers' lobbying methods sometimes are not suitable, for example, Lithuanian farmers insufficiently value influence of press campaigns to European Union institutions decisions. Also Lithuanian farmers hold a faulty opinion that Lithuanian state officials have more influence in Common Agriculture Policy forming than European Union institutions do. Lithuanian farmers did not achieve their main goal - to equalize direct payments to those of Western European countries. Lithuanian farmers' competitors are agricultural organisations from another European countries, and those organisations are more successful in lobbying activities, mostly because they have long lobbying traditions in their own countries.

Lithuanian agricultural organisations could form lobbying coalitions with agricultural organisations from another European states, which have the same interests. If Lithuanian farmers use organic farming, they will have support of environment protection organisations and politicians. It will be difficult for Lithuanian farmers to defend their position in European Union institutions without those allies, because Lithuanian agricultural organisations are not widely known in the key institutions. Also Lithuanian agricultural organisations unite a small number of members and small resources.

Keywords: pluralism, corporatism, clientelism, agrolobbyism, Lithuanian agricultural interest groups, European Commision, European Parlament, European Council, Lithuania, interests.

Vygandas Paulikas, Mykolo Romerio universiteto Politikos ir vadybos fakulteto Politikos mokslu instituto profesorius. Mokslinių tyrimų kryptys: politikos mokslai.

Vygandas Paulikas, Mykolas Romeris University, Faculty of Politics and Management, Institute of Political Sciences, Professor. Research interests: political sciences.

Linas Jonas Gustas, Mykolo Romerio universiteto Politikos ir vadybos fakulteto Politikos mokslų instituto ekologijos ir aplinkotyros magistras, politikos mokslų magistras. Mokslinių tyrimų kryptys: politikos mokslai, aplinkos apsauga.

Linas Jonas Gustas, Mykolas Romeris University, Faculty of Politics and Management, Institute of Political Sciences, Master of Ecology and Environmental Studies, Master of Political Sciences. Research interests: political sciences, environment protection. 